This manuscript is a non-peer reviewed preprint submitted to EarthArXiv. This preprint was submitted on 29 September 2021 to Earth and Planetary Science Letters for peer review. During the peer-reviewing process, its structure and content may change. If accepted, the final version of this manuscript will be available via the 'peer-reviewed publication DOl' link on the righthand side of this webpage.

\title{
Late Eocene-early Oligocene paleoenvironmental changes recorded at Lühe, Yunnan, southwestern China
}

Vittoria Lauretano1, Caitlyn R. Witkowski ${ }^{*}$, Alex Farnsworth², Shu-Feng $\mathrm{Li}^{3}$, Shihu $\mathrm{Li}^{4,5}$, Jan Peter Mayser ${ }^{1}$, B. David A. Naafs ${ }^{1}$, Robert A. Spicer ${ }^{3,6}$, Tao Su ${ }^{3}$, He Tang ${ }^{3,7}$, Zhekun Zhou ${ }^{3}$, Paul J. Valdes ${ }^{2}$, Richard D. Pancost ${ }^{1}$

${ }^{1}$ Schools of Chemistry and Earth Sciences, and Cabot Institute, University of Bristol, BS8 $1 \mathrm{TS}$

${ }^{2}$ School of Geographical Sciences and Cabot Institute, University of Bristol, Bristol, BS8 1SS, UK

${ }^{3}$ CAS Key Laboratory of Tropical Forest Ecology, Xishuangbanna Tropical Botanical Garden, Chinese Academy of Sciences, Mengla 666303, China

${ }^{4}$ State Key Laboratory of Lithospheric Evolution, Institute of Geology and Geophysics, Chinese Academy of Sciences, Beijing 100029, China

${ }^{5}$ Lancaster Environment Centre, Lancaster University, LA1 4YQ, Lancaster, UK

${ }^{6}$ School of Environment, Earth and Ecosystem Sciences, The Open University, Walton Hall, Milton Keynes, MK7 6AA, UK

${ }^{7}$ State Key Laboratory of Isotope Geochemistry, Guangzhou Institute of Geochemistry, Chinese Academy of Sciences, Guangzhou 510640, China.

*Corresponding author: caitlyn.witkowski@bristol.ac.uk @caitwitkowski 


\section{Abstract}

2 During the late Eocene to the early Oligocene, marine records document a globally congruent record of declining carbon dioxide concentrations, Antarctic icesheet growth, and associated reorganisation of the global climate system. In contrast, the few existing terrestrial records demonstrate high heterogeneity of environmental change and are difficult

6 to reconcile with those of the oceanic realm. Global drivers for climatic change are particularly difficult to disentangle from regional ones, especially those caused by the complex tectonic evolution of the Tibetan region and its influence on the Asian monsoon system and vegetation. Here, we reconstruct the climatic and environmental history from the late Eocene into the early Oligocene at Lühe Basin, Yunnan, China, a key sedimentary repository along the SE margin of the Tibetan Plateau and an important region for assessing Asian monsoon changes. We investigate a 340-m long section via a multi-proxy approach and climate model simulations. The organic geochemical proxies, via $n$-alkanes, terpenoids, and hopanes, suggest that thermally immature sediments were deposited in a terrestrial flood plain basin that was primarily occupied by gymnosperms and angiosperms. Branched glycerol diakyl glycerol tetraethers indicate relatively stable temperatures (ca. $10^{\circ} \mathrm{C}$ ) throughout the section, including across the Eocene-Oligocene boundary. This temperature, cooler than the modern-day average for this site $\left(\right.$ ca. $\left.15^{\circ} \mathrm{C}\right)$, suggests that this area has not undergone significant uplift since the Oligocene. To further contextualize our data, we tested a suite of climate model simulations with varying $p \mathrm{CO}_{2}$, paleogeography, and Tibetan topography across the Eocene-Oligocene boundary. This data-model comparison suggests that a response to regional factors might explain the absence of a pronounced cooling at Lühe across the Eocene-Oligocene boundary, supporting the emerging picture that the global expression of the EOT in terrestrial environments is more complex than indicated by the marine record.

Keywords: brGDGTs, terrestrial temperature, biomarker, Tibet, E-O transition, monsoon 


\section{Highlights:}

29 - Depositional environment primarily terrestrial flood plain basin, with gymnosperms

30 - Relatively stable mean annual temperatures (ca. $10^{\circ} \mathrm{C}$ ) across EOT

31 - Eastern Tibet at its current height since at least the EOT

32 - Data-model comparison suggests regional factors may explain lack of cooling at EOT

33 - Global expression of the EOT in terrestrial environments is highly heterogenous 


\section{Introduction}

From the late Eocene to the early Oligocene, Earth's climate transitioned from an icefree warmhouse world to icehouse world with large continental ice sheets. In deep-sea benthic records, the long-term cooling trend that started in the late Eocene reached its maximum late Paleogene expression across the Eocene-Oligocene Transition (EOT 34 Ma, e.g., Westerhold et al., 2020 and references therein), as recorded by a rapid increase in the $\delta^{18} \mathrm{O}$ of benthic foraminifera that reflect cooling and the onset of widespread Antarctic glaciation. The main hypothesis attributes this transition to the long-term drawdown of atmospheric $\mathrm{pCO}_{2}$ (Anagnostou et al., 2016; DeConto and Pollard, 2003; Lauretano et al., 2021), although others invoke the main driver as the establishment of the Antarctic Circumpolar Current (ACC) and reorganization of oceanic gateways that led to the thermal isolation of Antarctica (e.g., Bijl et al., 2013). The cooler conditions persisted through most of the Oligocene until at least $26 \mathrm{Ma}$, when deep-sea benthic records indicate a warming phase and reduced extent of the Antarctic ice sheets (Westerhold et al., 2020).

While marine records are well-documented across this period, less is known about the terrestrial expression of Eocene-to-Oligocene; the relatively few available terrestrial records indicate strong heterogeneity of responses in environmental change (e.g., Hren et al., 2013; Lauretano et al., 2021; Sheldon et al., 2016, 2012; Zanazzi et al., 2007). Even fewer records document changes occurring in the Asian continental interior across this critical climatic transition; here, the few available terrestrial records indicate regional aridification and cooling in NE Tibet (e.g., Zanazzi et al., 2007). For example, the radiometrically dated plant-fossil assemblages from the SE margin of Tibet reveal a composition change from sub-tropical/warm-temperate to cool-temperate across the late Eocene into the early Oligocene (Su et al., 2019b), possibly reflecting either secular climate change, the uplift of this area to its modern-day elevation, or a combination of both.

The complex topographic and tectonic evolution of Tibet during the Cenozoic (Spicer et al., 2020a, and references therein), following the India-Eurasia continental collision during 
the early Paleogene, is likely linked with regional climatic responses, especially in the Asian monsoon system (Farnsworth et al., 2019; Huber and Goldner, 2012). In addition to regional climatic changes, Asia was also characterized by heterogenious and regionally complex changes in biodiversity (e.g., Li et al., 2021). For example, the changing Tibetan landscape likely profoundly impacted Yunnan, one of Asia's biodiversity hotspots, situated in southwestern China along the SE Tibetan margin (Li et al., 2020; Spicer et al., 2020a). However, the lack of other (well-dated) sections has hindered attempts to correlate these interior locations to the global Cenozoic climate trends extrapolated from marine records. Reconstructing the climatic history of sedimentary basins along the margin of Tibet, in the context of a detailed temporal framework, is crucial to understanding the connection between topographic relief and climate, their influence on the Asian monsoon system, and the link to global climate.

Although modelling and paleobotanical efforts have recently been made to better constrain late Paleogene climate and biota throughout the Tibetan region (Su et al., 2020, 2019a), few have used quantitative organic geochemical proxies. Here, we reconstruct the environment in the Lühe basin (Yunnan province, China) by first determining the thermal maturity of the organic matter via e.g., bacteria-derived hopanes and eukaryote-derived $n$ alkanes, and then teasing out the organic sources and environmental conditions through gymnosperm-derived diterpenoids, angiosperm-derived triterpenoids, and eukaryote-derived $n$-alkanes. We then reconstruct mean annual temperatures using branched glycerol dialkyl glycerol tetraethers (brGDGTs), membrane-spanning lipids likely synthesized by bacteria and widely used as paleothermometers. Using these proxies, we present a new environmental and temperature reconstruction from the Lühe coalmine section spanning the latest Eocene to the early Oligocene, as constrained by magneto- and radio-isotopic dating. Moreover, we compare our results with climate model simulations through model-data comparison to assess the regional impact of secular climate change through the EoceneOligocene (E-O) transition. 


\section{Materials and Methods}

90

91

92

93

94

\subsection{Geological context}

The Lühe Basin is located in Nanhua County along the southern side of the Chuxiong fault, situated in central Yunnan Province, southwestern China (Fig. 1). As an understudied midway point between southern China and Tibetan, the Lühe Basin is considered a key location to reconstruct structural and paleoclimatic evolution along the SE margin of Tibet (Li et al., 2020).

Sediment in the Lühe basin was initially assigned to the late Miocene based on palynological and floral evidence, as well as regional stratigraphic correlations (Xu et al., 2008; Zhang et al., 2007). However, U-Pb zircon ages from volcanic ashes in Lühe town indicated an age of $\sim 33 \mathrm{Ma}$ (Linnemann et al., 2018), backdating at least part of the Lühe Basin to the earliest Oligocene. More recently, Li et al. (2020) further constrained this age by providing a new magneto- and radio-isotopic framework for the sedimentary succession exposed in the close-by Lühe coalmine $\left(25^{\circ} 10^{\prime} \mathrm{N}, 101^{\circ} 22^{\prime} \mathrm{E}\right.$; Fig. 1). The new ${ }^{40} \mathrm{Ar} /{ }^{39} \mathrm{Ar}$ dating of feldspars within volcanic ashes exposed in the lower portion of the coalmine provides an age of $33.32 \pm 0.36 \mathrm{Ma}$, in agreement with zircon-derived $\mathrm{U} / \mathrm{Pb}$ ages from the Lühe town section, $2.6 \mathrm{Km}$ southeast of the Lühe coalmine (Linnemann et al., 2018).

Magnetostratigraphic interpretation of the Lühe coalmine constrains this succession to span Chrons C15n and C9n (ca. 35-26 Ma, Gradstein, 2012), with an average sedimentation rate of $\sim 48 \mathrm{~cm} / \mathrm{kyr}$, consistent with the rates found in other basins around the Tibetan Plateau (Li et al., 2020). The Lühe coalmine succession comprises alternations of organic-rich marls, mudstones, sandstones, and lignite (immature fossilised peat) deposits (Fig. 1). A thick coal interval $(\sim 4 \mathrm{~m})$ at $\sim 50 \mathrm{~m}$ from base of the coal mine contains 11 volcanic ash layers, some of which were used for dating. The measured $\sim 340$-m thick profile was logged in 2018 along the SE margin of the exposed Lühe coalmine and is stratigraphically correlated with that of Li et al. (2020) (Fig.1). 


\subsubsection{Sample preparation}

A total of 56 samples were analysed for organic geochemistry in order to determine

118 the preservation state of the sediments, the paleoclimatic conditions, and the paleovegetation. Samples were extracted using a microwave-assisted extraction system with dichloromethane $(\mathrm{DCM})$ and methanol $(\mathrm{MeOH})(9: 1 \mathrm{v} / \mathrm{v})$. The resulting total lipid extract (TLE) was eluted with alumina column chromatography into an apolar fraction using hexane:DCM (9:1 v/v) and a polar fraction using DCM:MeOH (1:2 v/v). Apolar fractions were then analyzed via GC-MS and polar fractions were analyzed via HPLC-MS. For a detailed description of the analytical proceedures, see Supplementary Material.

\subsubsection{Indices for thermal maturity}

The apolar fraction contains compounds predominantly derived from plant, algal, and bacterial communities. Bacteria-derived hopanes and eukaryote--derived $n$-alkanes were used to assess the degree of thermal maturity of the organic matter preserved in the sediments, as high thermal maturity may bias the preservation of organic matter and thus the fidelity of our reconstructions. Here we calculated the stereochemistry of the $\mathrm{C}_{31}$ hopane at the $C-17$ and -21 positions, expressed as the $\beta \beta /(\beta \beta+\alpha \beta+\beta \alpha)$ ratio, which decreases with increasing thermal maturity (Fig. 2). To provide supplementary constraints on the thermal maturity, we also calculated the carbon preference index $(\mathrm{CPI})$, which measures the odd-over-even preference of mid- and long-chain $n$-alkanes. Odd-carbon-number $n$-alkanes are preferentially biosynthesised, meaning biological distributions have high CPIs; this CPI decreases with both degradation and thermal maturity. Here, CPI is calculated as ( $\Sigma$ odd

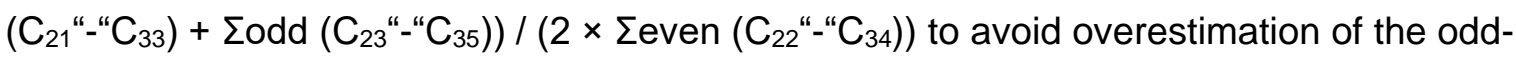
over-even preference (Marzi et al., 1993).

\subsubsection{Indices for vegetation and environmental reconstructions}

140 Eukaryote-derived compounds (i.e., $n$-alkanes, diterpenoids, triterpenoids) were used to

141 identify vegetation and environmental conditions. The average chain length (ACL) of $n$ - 
142 alkanes can be indicative of the organic matter source and is calculated as $A C L=\Sigma\left(C_{n} \times n\right) /$

$143 \Sigma\left(C_{n}\right)$ (Eglinton and Hamilton, 1967), here based on odd $n$-alkane chain-lengths from $\mathrm{C}_{21}$

144 through $\mathrm{C}_{33}$. The $\mathrm{P}$-aqueous ratio $\left(P_{\text {aq }}\right.$, calculated as $P_{\text {aq }}=\left(\mathrm{C}_{23}+\mathrm{C}_{25}\right) /\left(\mathrm{C}_{23}+\mathrm{C}_{25}+\mathrm{C}_{29}+\right.$

$\left.145 \mathrm{C}_{31}\right)$, Ficken et al., 2000) and the $C_{23} /\left(C_{23}+C_{31}\right)$ index (Nott et al., 2000) are generally

146 associated with wetland conditions, given that $C_{23}$ and $C_{25} n$-alkanes are produced by

147 Sphagnum mosses and some submerged vascular macrophytes but are generally absent in

148 higher plants. CPI, as described in 2.2.2, was used as supplementary information for

149 interpreting terrestrial input.

$150 \quad$ 2.2.4 brGDGT indices for MAAT and $\mathrm{pH}$

The polar fractions contained brGDGTs, membrane-spanning lipid biomarkers used to reconstruct mean annual air temperature (MAAT) and pH (De Jonge et al., 2014; Naafs et al., 2017a, 2017b; Weijers et al., 2007). Although impossible to rule out, seasonal temperature fluctuation is not considered to affect the temperature signal since 1) there is no apparent seasonal pattern in mid-latitude soils (Weijers et al., 2011); and 2) in the case of peat settings, bacterial production is concentrated at depths below the water table, where seasonal variability converges in mean annual temperatures (Naafs et al., 2017b). based on the distribution of brGDGTs in mineral soils (Weijers et al., 2007). This was later updated by De Jonge et al. (2014), who developed two new temperature calibrations, one based on the temperature-dependence of 5-methyl brGDGTs alone (MBT' ${ }_{5 \mathrm{me}}$ ), that excludes the possibly pH-dependant 6-methyl brGDGTs:

$$
\mathrm{MBT}^{\prime}{ }_{5 \mathrm{me}}=(\mathrm{la}+\mathrm{lb}+\mathrm{lc}) /(\mathrm{la}+\mathrm{lb}+\mathrm{lc}+\mathrm{Ila}+\mathrm{Ilb}+\mathrm{Ilc}+\mathrm{IIla})(\text { Fig. S1 })
$$

$$
\operatorname{MAT}\left({ }^{\circ} \mathrm{C}\right)=-8.57+31.45 \times \mathrm{MBT}^{\prime}{ }_{5 \mathrm{me}}\left(\mathrm{n}=231, \mathrm{R} 2=0.64, \mathrm{RSME}=4.9^{\circ} \mathrm{C}\right)
$$
brGDGTs: 
Further revision of the available global soil brGDGT data excludes from the compilation 6methyl dominated brGDGTs from arid and/or alkaline soils (Naafs et al., 2017a), leading to

$$
\text { MAAT }_{\text {soil }}=40.01 \times \mathrm{MBT}^{\prime}{ }_{5 \mathrm{me}}-15.25\left(\mathrm{n}=350, \mathrm{R}^{2}=0.60, \mathrm{RMSE}=5.3^{\circ} \mathrm{C}\right) \text {. }
$$

The degree of cyclization of branched tetraethers (CBT) correlates with $\mathrm{pH}$ in mineral soils (Weijers et al., 2007). The CBT index was later revised into CBT' (De Jonge et al., 2014), including 6-methyl brGDGTs and improved the correlation with $\mathrm{pH}$ :

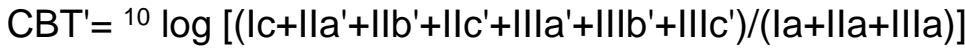

$$
\begin{aligned}
& \mathrm{pH}=7.15+1.59 \times \mathrm{CBT}^{\prime},\left(\mathrm{n}=221, \mathrm{R}^{2}=0.85, \mathrm{RSME}=0.52\right)
\end{aligned}
$$

Most work on brGDGTs is based on mineral soils, but brGDGTs are particularly abundant in peat deposits (Sinninghe Damsté et al., 2000; Naafs et al., 2019). The relationship between environmental parameters and the distribution of brGDGTs in peats led to the first peat-specific temperature and $\mathrm{pH}$ calibrations based on a global peat database (Naafs et al., 2017b). The relationship between MBT' ${ }_{5 m e}$ and MAAT is in this case expressed as:

$$
\operatorname{MAAT}_{\text {peat }}\left({ }^{\circ} \mathrm{C}\right)=52.18 \times \mathrm{MBT}^{\prime}{ }_{5 \mathrm{me}}-23.05\left(\mathrm{n}=96, \mathrm{R}^{2}=0.76, \mathrm{RMSE}=4.7^{\circ} \mathrm{C}\right)
$$

while the correlation between brGDGTs and $\mathrm{pH}$ is defined as:

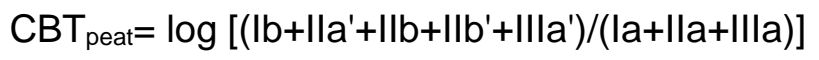

$$
\begin{aligned}
& \mathrm{pH}=8.07+2.49 \times \mathrm{CBT}_{\text {peat }},\left(\mathrm{n}=51, \mathrm{R}^{2}=0.85, \mathrm{RSME}=0.8\right)
\end{aligned}
$$

In this study, we applied and compared the soil MAT calibrations by De Jonge et al. (2014) and Naafs et al. (2017a), and the peat-specific calibration by Naafs et al. (2017b) (see results).

The Branched vs. Isoprenoidal Tetraether (BIT) index was used to indicate the relative input of terrestrial and marine organic matter, defined by (Hopmans et al., 2004) as:

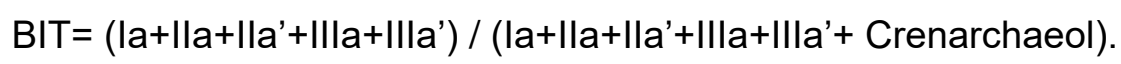

In addition to bacterial brGDGTs (Fig. S1), this includes the isoprenoidal (iso)GDGT known as crenarchaeaol, which is produced by Thaumarchaeota and is especially abundant in marine settings. 
Here, we utilised a suite of climate model simulations to assess the impact on Asian climate in the context decreasing atmospheric concentrations of carbon dioxide $\left(p \mathrm{CO}_{2}\right)$ and the formation of a Southern Hemisphere icesheet through the E-O transition. Using the late Eocene (Priabonian stage) and Oligocene (both Rupelian and Chattian stages) boundary conditions, we employed HadCM3BL-M2.1aD (Valdes et al., 2017), a fully coupled oceanatmosphere and dynamic vegetation General Circulation Model (GCM) with a $3.75 \times 2.5$ latitude by longitude spatial grid ( $300 \mathrm{~km}), 19$ vertical levels in the atmosphere, and 20 vertical levels in the ocean. HadCM3BL-M2.1aD, a primary model of the IPCC AR3 to AR5 experiments, has shown spatio-temporal skill in reproducing the modern observed Asian monsoon and paleo-monsoon (Farnsworth et al., 2019), providing confidence in its thermodynamic and hydrologic response to perturbed forcing for the current region of interest.

Model boundary conditions (topography, bathymetry, and ice sheet configurations; at

$2100.5 \times 0.5^{\circ}$ resolution and downscaled to model resolution) for each geologic stage,

211 Priabonian ( $\sim 36 \mathrm{Ma})$, Rupelian ( $\sim 31 \mathrm{Ma})$, and Messinian ( $25 \mathrm{Ma})$, are provided by Getech

212 Plc. Stage-specific solar luminosity was calculated using the methods of (Gough, 1981).

$213 \mathrm{pCO}_{2}$ values were prescribed at $1120 \mathrm{ppm}$ for the Priabonian and $560 \mathrm{ppm}$ for the Rupelian

214 and Chattian, consistent with the Phanerozoic $p \mathrm{CO}_{2}$ compilation of (Foster et al., 2017;

215 Witkowski et al., 2018).

216 Each experiment was run for 12,422 model years to allow surface and deep ocean to

217 reach equilibrium and to achieve a state with no net energy imbalance at the top of the

218 atmosphere. This is fundamental as ocean circulation can take many thousands of model

219 years to establish its equilibrium state, with a significant influence on the climate signal

220 leading to a potentially erroneous state if not adequately spun-up (Farnsworth et al., 2019).

221 Climate means are calculated from the last 100-years of each simulation. Time-varying

222 latitude and longitude plate paleo-rotations are provided for the Lühe Basin for each stage to 
allow for accurate comparison within the model. The paleo-coordinates $\left(21.1^{\circ} \mathrm{N}\right)$ for Lühe were calculated using the Getech plate model.

225

226

227

228

229

230

231

232

233

234

235

236

237

238

239

240

241

242

243

244

245

246

247

248

249

\section{Results \& Discussion}

\subsection{Thermal maturity of sediments}

The apolar fractions were used to estimate thermal maturity (Figs. 2, 3). The $C_{31}$ hopane configuration ratio of $\beta \beta$ / $(\beta \beta+\alpha \beta+\beta \alpha)$ ranges from 0.0 to 0.7 (from high to low thermal maturity, respectively) with a mean of $0.4 \pm 0.2 \sigma$ (Fig. 3A). Values are slightly lower in the bottom $\sim 30 \mathrm{~m}$ of the section. Although variable, most values are over 0.3 and there is no consistent trend through the section. Instead, it appears that the organic matter is relatively immature with an admixture of mature, reworked organic matter in some low-TOC intervals. The CPI ranges from 1.9 to 9.4 with a mean of $4.9 \pm 1.6 \sigma$ (Fig. 3B). These CPI values likewise suggest that these sediments are relatively immature, although the variation reflects the dynamic depositional environment.

\subsection{Vegetation and environmental reconstruction}

Throughout the section, the $n$-alkane distribution shows a strong odd-over-even preference (Fig. 3B), with a CPI ranging from 1.9 to 9.4 with a mean of $4.9 \pm 1.6 \sigma$, suggesting this is primarily terrestrial in origin. In most of these sediments, the apolar fractions are dominated by the $\mathrm{C}_{29} n$-alkane, followed by a high abundance of the $\mathrm{C}_{27}$ and then $\mathrm{C}_{31} n$-alkanes (Figs. $2 \mathrm{~A} ; 4$ ), suggesting dominance of higher plants. The $A C L$ ranges from 26.1 to 29.6 with a mean of $28.4 \pm 0.6 \sigma$ (Fig. 3C). This relatively high CPI (Fig. 3B), high ACL (Fig. 3C), and dominance of the $\mathrm{C}_{29} n$-alkane (Fig. 2A, 4) suggests that the vegetation at this site was likely dominated by woody angiosperms and gymnosperms. More specifically, the ACL of 28.4 is more likely associated with deciduous rather than evergreen angiosperms.

Several samples also contained diterpenoids and triterpenoids (Fig. 2A), indicative of gymnosperms and angiosperms respectively, which may provide further insights into the type of vegetation at this site. Throughout the section, the abietane-based diterpenoids (18- 
norbietane at 21.4 and $268.0 \mathrm{~m}, 18$-norabieta-8,11,13-triene at $21.4 \mathrm{~m}, 10,18$-bisnorabieta5,7,9(10),11,13-pentaene at $21.4 \mathrm{~m}$, and dehydroabietane at 228.5 and $268.0 \mathrm{~m}$ ) are indicative of the Pinaceae family. The inclusion of the Pinaceae family in the vegetation is further supported by the presence of simonellite (228.5 and $268.0 \mathrm{~m}$ ), a diterpene present in conifer resin. Evidence of conifers in the catchment area is further suggested by the presence of norpimarane at depths 21.4 and $268.0 \mathrm{~m}$, which is particularly abundant in Pinus, Larix, and Picea. Several samples also contained triterpenoids, including tetramethyloctahydrochrysene (22.4 m) and Des-A-lupane (40.7, 105.6, 289, $301.9 \mathrm{~m})$, compounds synthesized by nearly all angiosperms. The more frequent abundance of diterpenoids-overtriterpenoids in these sediments suggest that this environment was likely dominated by gymnosperms with some angiosperms, although it should be noted that taphonomy processes can skew plant preservation and associated biomarker distributions. Our biomarker-based vegetation reconstruction is consistent with the plant fossil assemblage recovered from the nearby Lühe town section, which is age-correlated with the basal portion of our coal mine section. At the town section, previous work identified 38 floral genera, assigned to 26 angiosperms, 6 gymnosperms, and 4 ferns (Tang et al., 2020). Analyses of the paleo-vegetation reveal that trees and shrubs dominated most of the section, as also indicated by tree stumps, fallen logs, and branches present throughout the section (Yi et al., 2003). The ACL values are also supported by palynological results, which indicate a temperate deciduous broadleaved flora mixed with some evergreen broadleaved taxa and conifers (Tang et al., 2020). Evergreen oaks (Quercus) and alder (Alnus) were

271 identified, and palynomorphs were dominated by Quercoidites (43\%), Titricolpites (12.5\%), 272 Pinuspollenites (6.93\%), and Piceapollis (0-18.6\%). These are not necessarily representative of in-situ assemblages given that pollen might have been blown/washed into

274 the basin from the surrounding (and possibly higher) areas but are consistent with the biomarker assemblages in our samples. 
277 between 0.2 and 0.5 with a mean of $0.4 \pm 0.2 \sigma . A P_{\mathrm{aq}}<0.23$ is considered indicative of 278 terrestrial plant waxes, while $>0.48$ is common for submerged and floating macrophytes 279 (Ficken et al., 2000). Because our $P_{\text {aq }}$ sits in the middle of these ranges, this may have been a wet terrestrial environment, like a floodplain. This is further supported by the sedimentary succession (Fig. 3) and high abundance of Equisetum cf. pratense seen in the coalmine section (Zhang et al., 2007), which is indicative of wet terrestrial environments. However, the variation is again representative of a dynamic depositional environment.

Notably, the apolar distribution of two sediment depths (26.7 and $58.5 \mathrm{~m}$ ) appear different from the rest of the section (Fig. 3B). These two sediment depths lie more than $2 \sigma$ outside the ACL and $P_{\text {aq }}$ distribution (Fig. 3C-D), with the ACLs being particularly low (25.2 and 25.3 respectively, relative to the average of $27.6 \pm 0.8 \sigma$ ) and the $P_{\text {aq }}$ being particularly high ( 0.9 and 0.8 respectively, relative to the average of $0.3 \pm 0.2 \sigma)$. Although these two sediment depths still contain $n$-alkanes with a strong odd-over-even preference and long chain-lengths associated with higher plants (i.e., $\mathrm{C}_{27}, \mathrm{C}_{29}$, and $\mathrm{C}_{31}$ ), they show a clear $\mathrm{C}_{23}$ and $\mathrm{C}_{25}$ dominance, which is considered a robust signature for either Sphagnum peat mosses (Nott et al., 2000) or aquatic plants (Ficken et al., 2000). Therefore, these two outlier horizons may represent swampy environments or even open water conditions. Interbedded lignites found throughout the section further confirm that this was (at times) a peat-forming environment. This environment is consistent with a riverine floodplain, as also supported by the presence of sedimentary structures of river channels and sedimentological evidence of intervals of water-logging conditions.

Taken together, our biomarker results are compatible with a terrestrial environment (likely a flood plain) with organic-rich soils derived from swamps, colluvium, occasional peatforming, and wet areas. We do see evidence for abundant terrestrial biomarkers (e.g., leaf waxes, terpenoids indicative of woody gymnosperms and angiosperms, and soil bacterial lipids) and we do not see evidence for aquatic inputs (e.g., low CPI, low ACL, and strong 
presence of algal biomarkers). The specific higher plant biomarkers are also consistent with

304 this area being covered in deciduous and evergreen broad-leaved mixed forests, as observed in the nearby Lühe town section (Tang et al., 2020).

\subsection{Climate reconstruction using GDGT indices}

Lithologies in the Lühe coalmine section vary; lithologies include sands, mudstones, and coal/lignite layers, and are interbedded with fossil remains of wood (logs and branches) and leaves (Fig. 3). Such lithological variability is indicative of a dynamic paleoenvironment,

310 likely a flood plain, where deposition of swamp-derived organic-rich soils were interspersed

311 with colluvium, occasional peat mire, and shallow stagnant environments (Xu et al., 2008).

312 This dynamic environment poses a challenge for the application of a univocal brGDGT

313 paleothermometer calibration. Therefore, we rely on a series of characteristics stemming

314 from field observations, TOC (wt\%) data, and organic geochemical analyses to constrain the type of lithology and paleoenvironment, and then apply three different brGDGT-temperature calibrations (Fig. 5).

Most sediments $(n=46)$ have a TOC $(w t \%)$ ranging between $0.1-23 \%$ with the majority $<3 \%$ (Fig. 5), consisting of the lithologies categorised from mudstone to silty sandstones. The remaining sediments $(n=10)$ have TOC (wt\%) ranging between $40-63 \%$; these high TOC ranges are indicative of organic-rich environments, consistent with the presence of coal layers identified in the stratigraphy. Samples from sand lithologies were tested and excluded from the sample set as they did not yield sufficient organic matter for analysis (Fig. 5).

Of all samples analysed $(n=56), 38$ yielded sufficient brGDGTs for paleotemperature estimates (Fig. 5). For samples with TOC (wt\%) $<23 \%(n=33)$, we cannot further constrain the type of paleoenvironment and/or the source of bacterial production (e.g., lacustrine vs soil). Thus, we apply both the MAT and pH soil calibration by De Jonge et al. (2014) and MAT soil calibration of Naafs et al. (2017a) (Fig. 5). For the 
samples with TOC $(w t \%)>23 \%(n=5)$, identified as lignites/coals, we further apply the peat-specific temperature and pH calibration by Naafs et al (2017b) (Fig. 5). MAAT values range from 4.9 to $14.7^{\circ} \mathrm{C}\left( \pm 4.9^{\circ} \mathrm{C}\right)$ using the de Jonge et al. (2014) soil calibration and between 3.8 and $14.4^{\circ} \mathrm{C}\left( \pm 5.3^{\circ} \mathrm{C}\right)$ using the Naafs et al. (2017a) soil calibration, with average temperatures of ca. $9-10^{\circ} \mathrm{C}$. The Naafs et al. (2017b) peat-specific calibration yielded MAAT values from 5.3 to $15.4^{\circ} \mathrm{C}\left( \pm 4.7^{\circ} \mathrm{C}\right)$ for the five lignite samples, with warmer values at the top of the section. Temperature estimates throughout the section show some variability, possibly due to the mixing in the rapidly changing environments. However, the overall trend, highlighted by the 2-point moving average (Fig. 5), shows that average temperatures remained rather stable throughout (regardless of calibration), with only a slight warming towards the top of the section.

$\mathrm{pH}$ values range between 3 and 6 , with an average value of 4 , and show increased variability in the upper interval of the section where $\mathrm{pH}$ increases (Fig. 5; 310-340 m). These values are consistent with an acidic peat environment. The BIT index is consistently above

3430.87 (Fig. 5), indicating a dominance of brGDGTs over crenarchaeol and consistent with a

344 terrestrial-dominated source of organic matter throughout the section (Hopmans et al., 345 2004).

346 Mean annual temperatures across this section are consistent with a temperate climate, 347 which persisted without major fluctuations from the end of the Eocene through to the early

348 Oligocene. We do not find evidence of significant cooling across the Eocene-Oligocene 349 transition, which would have been preserved within the first $60 \mathrm{~m}$ of the section, based on 350 radio-isotopic ages ( $\mathrm{Li}$ et al., 2020). This could be due to imprecise age constraints, or to the 351 presence of a hiatus in the sequence, although the radio-isotopic datum in the lower portion of the section and the magnetostratigraphic interpretation of this section by Li et al. (2020) do not seem to support these hypotheses. Alternatively, our reconstruction shows that climate at Lühe remained relatively stable from the late Eocene to the early Oligocene and it 
did not experience the cooling observed at other terrestrial locations across the globe during the EOT (e.g., Zanazzi et al., 2007).

Our results fit with the emerging picture that the global expression of the EOT in terrestrial environments is highly heterogenous (e.g., Hren et al., 2013; Lauretano et al., 2021; Sheldon et al., 2016; Zanazzi et al., 2007). Terrestrial temperature records across this interval are derived from a variety of qualitative and quantitative proxies (e.g., paleobotanical, palynological, geochemical). Vegetation records provide the most extensive global dataset of changes across the EOT and generally show a variety of responses, partly influenced by local/regional factors and changes in precipitation. Northern hemisphere geochemical records also depict a range of different responses, with paleosol records from North America generally indicating no change or a $\sim 2-3^{\circ} \mathrm{C}$ cooling (Retallack, 2007) but also, for example, a more dramatic $\sim{ }^{\circ} \mathrm{C}$ temperature drop across the transition, as reconstructed by fossil teeth isotopic data (Zanazzi et al., 2007). In contrast, floral assemblages from the same region show a more protracted cooling from the early into the middle Oligocene (Retallack et al., 2004). Meanwhile, clumped isotope data from a freshwater gastropod shell from the Hampshire Basin (Isle of Wight, UK) indicate a $4-6{ }^{\circ} \mathrm{C}$ cooling from warm late Eocene estimates to the early Oligocene (Hren et al., 2013), while paleosol estimates from the Ebro Basin (Spain) suggest that temperature remained unvaried during this time (Sheldon et al., 2012). The response in southern hemisphere terrestrial temperatures vary, as well. Floral and isotopic records from Argentina indicate a 'quasistatic' climate across the Eocene and Oligocene (Kohn et al., 2015), but more recent data from volcanic glass stable hydrogen isotopes suggest that a $5^{\circ} \mathrm{C}$ cooling occurred across this the EOT (Colwyn and Hren, 2019). Evidence of cooling across the EOT is also reported in a peat-specific lignite record from SE Australia, showing an average cooling of $2.4{ }^{\circ} \mathrm{C}$ from the late Eocene to the earliest Oligocene, coeval with a shift toward cooler species in the palynological record from the same facies (Lauretano et al., 2021). 
382 change at the EOT, whereas marine reconstructions consistently suggest a global average 383 cooling of about $2.5^{\circ} \mathrm{C}$ in sea-surface and deep-sea temperatures (Hutchinson et al., 2021).

384 While we highlight that a relatively muted cooling of $<1-2{ }^{\circ} \mathrm{C}$ might be difficult to detect in our 385 proxy records, which are better suited for greater temperature oscillations (Naafs et al., 386 2017b), the results from this section represent one more puzzle piece in the terrestrial expression of the EOT and the possible influence of local factors on this response. consisted of a flood plain, hosting local swamps, colluvium, and occasional peat mires, as well as shallow submerged areas, dominated by terrestrial inputs. Modern-day mean annual temperatures in this area are of ca. $14.4-15.4^{\circ} \mathrm{C}$ (http://data.cma.cn/en), indicating that this location was most likely already at least its present-day elevation during the early Oligocene, supporting the hypothesis that local uplift had already taken place at this time (Spicer et al., 394 2020a).

\section{$395 \quad 3.4$ Climate model results}

We employed a fully coupled atmosphere-ocean GCM with a range of perturbed

397 Priabonian and Chattian boundary conditions to investigate potential mechanisms for our temperature proxy results. We tested the effects of different parameters on temperature and precipitation in this region (Table 1) across the E-O boundary and explore whether it was sensitive to a drawdown in $\mathrm{pCO}_{2}$ and the concurrent development of an Antarctic icesheet. Moreover, we compare our results with modelled temperature and precipitation responses under Chattian boundary conditions to test for Oligocene conditions with no additional site elevation or latitudinal changes during this time. region $\left(0^{\circ} \mathrm{N}-60^{\circ} \mathrm{N}, 60^{\circ} \mathrm{E}-120^{\circ} \mathrm{E}\right)$, as seen in Table 1 , considering changes in $p \mathrm{CO}_{2}$, global paleogeography, and the site elevation as variables across the E-O boundary. For the regional impact, a decrease from $4 x$ to $2 x$ pre-industrial $p \mathrm{CO}_{2}$ across the $\mathrm{E}-\mathrm{O}$ boundary 
results in regional temperatures cooling by $\sim 6^{\circ} \mathrm{C}$, regardless of topographic changes of the

409 Tibetan Plateau (valley, plateau, or valley to plateau; Table 1, simulations 1-3). When

410 assuming no change in $\mathrm{pCO}_{2}$, global changes in paleogeography from a Priabonian to

411 Chattian configuration produce a reduced impact on the climate of Asia, with a slight

412 increase in MAT of $1.5^{\circ} \mathrm{C}$ (Table 1, simulations 4-6). This is the result of regional changes to

413 gateways, including the retreat of the Paratethys sea and the formation of Antarctic ice

414 sheets. In all simulations including a change at the E-O boundary, MAP is similarly affected,

415 increasing by ca. $150-200 \mathrm{~mm} / \mathrm{yr}$ but this does not significantly vary amongst different

416 topographic configurations.

417 As our section spans to the late Oligocene, we also compare our proxy results with

418 model estimates calculated under Chattian boundary conditions. Under 2x pre-industrial

$419 \mathrm{pCO}_{2}$, the model reproduces an MAT of $\sim 19^{\circ} \mathrm{C} \pm 0.4$, for either a Tibetan topography with a

2.5-km valley or a 4.5-km plateau (Table 2) with seasonal changes varying from a coldmonth mean temperature (CMMT) of $\sim 12{ }^{\circ} \mathrm{C}$ to a warm-month mean temperature (WMMT) of $24^{\circ} \mathrm{C}$. These average estimates, although warmer than what we observe in our record, are still within error of the values we observe in the top interval of our proxy record $\left(15^{\circ} \mathrm{C} \pm\right.$ 4.7). The cooler temperatures shown by our proxy record could be due to the inclusion of organic matter from a wider catchment area in our biomarker data, including material washed in the basin from higher elevation surrounding the flood plain. This is compatible with the presence of sediment indicative of colluvium (fine mudstones, sandy beds) and the rich assemblages represented in the apolar fraction. The palynological results also suggested some conifers such as Abies, Picea and Pinus, may transferred from high elevation mountains nearby. However, despite being sparse, our lignite-based peat-specific MAAT estimates represent in-situ production and are largely in agreement with the other calibrations applied. Therefore, we are confident that our estimates provide a satisfying picture of the average temperatures at this location.

\section{$434 \quad 3.5$ The evolution of the Tibetan region and Eocene/Oligocene climate}


Based on our proxy data and model simulations, we note several possible places of agreement. Our GDGT-based temperatures suggest that there is minimal change across the section, with some potential warming towards the top of the section. Terrestrial temperature records, albeit sparse, suggest a more gradual $p \mathrm{CO}_{2}$ decline across the Eocene to the earliest Oligocene than marine records, and a less pronounced response at the E-O boundary. This is consistent with marine geochemical proxies, including boron isotope $\left(\delta^{11} \mathrm{~B}\right)$ records, that show that the decline in $\mathrm{pCO}_{2}$ occurred progressively from the middle to the

442 late Eocene (Anagnostou et al., 2016) and culminated in a further two-stepped decline at the 443 EOT. Marine records generally suggest a $\mathrm{pCO}_{2}$ decline from $1000 \mathrm{ppm}$ in the Priabonian 444 setting to 700 ppm during the Rupelian (Hutchinson et al., 2021), while stomatal records, for example, suggest $p \mathrm{CO}_{2}$ values drop from $630 \mathrm{ppm}$ in the late middle Eocene to ca. $365 \mathrm{ppm}$ in the late Eocene, just prior to the EOT (Steinthorsdottir et al., 2016). It is worth noting that

$447 \mathrm{CO}_{2}$-forced GCM and dynamic ice-sheet model experiments reproduce a threshold for 448 glaciation at around 780 ppm (DeConto and Pollard, 2003), from which a relatively small 449 drop in $p \mathrm{CO}_{2}$ would have been sufficient to initiate ice-sheet dynamics. Assuming that the stratigraphy at this site does encompass the E-O boundary, the temperature response at Lühe might reflect paleogeographic changes rather than the effect of a rapid and large drop in $\mathrm{pCO}_{2}$, as observed in the regional scale simulations (Table 1, simulations 4-6). The temperature decline of $\sim 6^{\circ} \mathrm{C}$ observed in the climate model simulations driven by a drawdown of $p \mathrm{CO}_{2}$ are in line with the spread of available terrestrial proxy data (Hutchinson et al., 2021; Lauretano et al., 2021), and local factors might hinder the temperature response at our site. Additionally, the simulated drop in $\mathrm{pCO}_{2}$ from $4 \mathrm{x}$ to $2 \mathrm{x}$ pre-industrial levels might overestimate the actual withdrawal of $p \mathrm{CO}_{2}$ occurring across the E-O boundary, which might have been closer to a factor of $1.6 \mathrm{x}$, based on the best fit in ensemble means (Foster et al., 2017; Hutchinson et al., 2021). A more gradual $p \mathrm{CO}_{2}$ decline, as well as a smaller magnitude of drawdown, might explain a less pronounced response in terrestrial temperatures at our site. 
463 results from a Bioclimatic Analysis of the palynoflora (Tang et al., 2020) and Climate Leaf 464 Analysis Multivariate Program (CLAMP) (Wolfe, 1993; Yang et al., 2011) which indicate an average mean annual temperature of $15.9^{\circ} \mathrm{C} \pm 2.36$, CMMT of $\sim 4.5^{\circ} \mathrm{C}$ and WMMT of 26.9 ${ }^{\circ} \mathrm{C}$ for the leaf assemblage preserved in the Lühe town section. These results demonstrate a large mean annual range of temperatures, with likely infrequent winter frosting and warm summers. This would suggest a warm temperate climate rather than subtropical, with taxa with frost sensitive leaves prone to winter deciduousness. Precipitation during the growing season averaged $2250 \mathrm{~mm} \pm 640$ while precipitation during the three consecutive wettest months (3-WET) and the three consecutive driest months (3-DRY) range between $1110 \pm$ 400 and $340 \pm 98 \mathrm{~mm}$ respectively (Table 3 ). However, the overall precipitation is likely overestimated in CLAMP, and particularly for the dry months in warm climates, because water is not a limiting growth factor for plant growing near to aquatic depositional sites 475 (Spicer et al., 2011).

476

\section{Conclusions}

We present a multi-proxy geochemical record to reconstruct paleoclimatic and paleoenvironmental conditions at Lühe, in central Yunnan, China, from the late Eoceneearly Oligocene. Plant and bacteria-derived biomarkers indicate that this site on the southeastern margin of Tibet represented a terrestrial flood plain environment, with occasionally submerged peat/swamp deposits. The abundance of terrestrial biomarkers indicative of woody gymnosperms and angiosperms is consistent with reconstructions of this area as covered by deciduous and evergreen broad-leaved forests, as observed for the nearby Lühe town section (Tang et al., 2020).

Mean annual temperatures, reconstructed using brGDGTs from bacterial lipids in soil and lignite samples, indicate average values of $9-10^{\circ} \mathrm{C}$, reaching maximum values of $\sim 15$

$488{ }^{\circ} \mathrm{C}$ towards the top of the section. This suggests stable climatic conditions, with the 
possibility of a slight warming in the upper portion of this section. Using a fully coupled

490 atmosphere-ocean GCM, we test a range of perturbed Priabonian and Chattian boundary

491 conditions across the Eocene-Oligocene boundary for both the local and regional scale,

492 including $\mathrm{pCO}_{2}$, paleogeography, and varying Tibetan topography configurations. The muted

493 response at our site might be due to the influence of local factors, as well as pointing to a

494 smaller and more gradual drawdown of $\mathrm{CO}_{2}$ across this transition, in line with results shown

495 by GCM simulations (DeConto and Pollard, 2003; Hutchinson et al., 2021). Factors including

496 regional and local response to paleogeographical conditions need further exploration, which

497 can only be possible with additional records, as well as contributing to the effort of

498 reconciling $\mathrm{pCO}_{2}$ reconstructions from marine and terrestrial records.

499

500 Acknowledgements

501 This research was carried out with funding from the joint UK-China Project administered by

502 the UK Natural Environment Research Council (NE/P013805/1) and the Natural Science

503 Foundation of China Project (No. 41661134049, 41772026) and an XTBG Visiting

504 Scholarship to RAS. ZZ thanks the Natural Science Foundation of China Project (No.

$50541661134049,42072024)$ and SFL thanks the Natural Science Foundation of China for the

506 Project funding (No. 41772026). We thank NERC (Reference: CC010) and NEIF

507 (www.isotopesuk.org) for funding and maintenance of the instrumentation used for this work

508 and Dr F. Sgouridis at the University of Bristol for technical assistance. B.D.A.N.

509 acknowledges funding through a Royal Society Tata University Research Fellowship. In

510 addition, NERC (Reference: CC010) and NEIF (www.isotopesuk.org) are thanked for

511 funding and maintenance of the GC-MS and HPLC-MS instrument used for this work. 
513 Anagnostou, E., John, E.H., Edgar, K.M., Foster, G.L., Ridgwell, A., Inglis, G.N., Pancost,

514

515

516

517

518

519

520

521

522

523

524

525

526

527

528

529

530

531

532

533

534

535

536

537

538 R.D., Lunt, D.J., Pearson, P.N., 2016. Changing atmospheric $\mathrm{CO}_{2}$ concentration was the primary driver of early Cenozoic climate. Nature 533, 380-384. https://doi.org/10.1038/nature17423.

Bijl, P.K., Bendle, J.A.P., Bohaty, S.M., Pross, J., Schouten, S., Tauxe, L., Stickley, C.E., McKay, R.M., Rohl, U., Olney, M., Sluijs, A., Escutia, C., Brinkhuis, H., Klaus, A., Fehr, A., Williams, T., Carr, S.A., Dunbar, R.B., Gonzalez, J.J., Hayden, T.G., Iwai, M., Jimenez-Espejo, F.J., Katsuki, K., Kong, G.S., Nakai, M., Passchier, S., Pekar, S.F., Riesselman, C., Sakai, T., Shrivastava, P.K., Sugisaki, S., Tuo, S., van de Flierdt, T., Welsh, K., Yamane, M., Röhl, U., 2013. Eocene cooling linked to early flow across the Tasmanian Gateway. Proceedings of the National Academy of Sciences 110, 9645-9650. https://doi.org/10.1073/pnas.1220872110.

Colwyn, D.A., Hren, M.T., 2019. An abrupt decrease in Southern Hemisphere terrestrial temperature during the Eocene-Oligocene transition. Earth and Planetary Science Letters 512, 227-235. https://doi.org/10.1016/J.EPSL.2019.01.052.

de Jonge, C., Hopmans, E.C., Zell, C.I., Kim, J.-H., Schouten, S., Sinninghe Damsté, J.S., 2014. Occurrence and abundance of 6-methyl branched glycerol dialkyl glycerol tetraethers in soils: Implications for palaeoclimate reconstruction. Geochimica et Cosmochimica Acta 141, 97-112. https://doi.org/10.1016/j.gca.2014.06.013.

DeConto, R.M., Pollard, D., 2003. Rapid Cenozoic glaciation of Antarctica induced by declining atmospheric CO2. Nature 421, 245-249.

Dupont-Nivet, G., Krijgsman, W., Langereis, C.G., Abels, H.A., Dai, S., Fang, X., 2007. Tibetan plateau aridification linked to global cooling at the Eocene-Oligocene transition. Nature 445, 635-8. https://doi.org/10.1038/nature05516.

Eglinton, G., Hamilton, R.J., 1967. Leaf Epicuticular Waxes. Author: Geoffrey Eglinton and Richard J. Hamilton Published by: American Association for the Advancement of 

https://doi.org/DOI: 10.1126/science.156.3780.1322.

541 Farnsworth, A., Lunt, D.J., O’Brien, C.L., Foster, G.L., Inglis, G.N., Markwick, P., Pancost,

542

543

544

545

546

547

548

549

550

551

552

553

554

555

556

557

558

559

560

561

562

563

564

565
R.D., Robinson, S.A., 2019. Climate Sensitivity on Geological Timescales Controlled by Nonlinear Feedbacks and Ocean Circulation. Geophysical Research Letters 46, 9880-9889. https://doi.org/10.1029/2019GL083574.

Farnsworth, Alex, Lunt, D.J., Robinson, S.A., Valdes, P.J., Roberts, W.H.G., Clift, P.D., Markwick, P., Su, T., Wrobel, N., Bragg, F., Kelland, S.J., Pancost, R.D., 2019. Past East Asian monsoon evolution controlled by paleogeography, not $\mathrm{CO}$. Science Advances 5, eaax1697. https://doi.org/10.1126/sciadv.aax1697.

Ficken, K.J., Li, B., Swain, D.L., Eglinton, G., 2000. An n-alkane proxy for the sedimentary input of submerged/floating freshwater aquatic macrophytes. Organic Geochemistry 31, 745-749. https://doi.org/10.1016/S0146-6380(00)00081-4.

Foster, G.L., Royer, D.L., Lunt, D.J., 2017. Future climate forcing potentially without precedent in the last 420 million years. Nature Communications 8, 1-8. https://doi.org/10.1038/ncomms14845.

Gough, D.O., 1981. Solar interior structure and luminosity variations. Solar Physics 74, 2134. https://doi.org/10.1007/BF00151270.

Gradstein, F.M., 2012. Introduction, The Geologic Time Scale 2012. Felix M. Gradstein, James G. Ogg, Mark Schmitz and Gabi Ogg. https://doi.org/10.1016/B978-0-44459425-9.00001-9.

Hopmans, E.C., Weijers, J.W.H.H., Schefuß, E., Herfort, L., Sinninghe Damsté, J.S., Schouten, S., 2004. A novel proxy for terrestrial organic matter in sediments based on branched and isoprenoid tetraether lipids. Earth and Planetary Science Letters 224, 107-116. https://doi.org/10.1016/j.epsl.2004.05.012.

Hren, M.T., Sheldon, N.D., Grimes, S.T., Collinson, M.E., Hooker, J.J., Bugler, M., Lohmann, K.C., 2013. Terrestrial cooling in Northern Europe during the Eocene-Oligocene 

transition. Proceedings of the National Academy of Sciences of the United States of America 110, 7562-7. https://doi.org/10.1073/pnas.1210930110.

Huber, M., Goldner, A., 2012. Eocene monsoons. Journal of Asian Earth Sciences 44, 3-23. https://doi.org/10.1016/j.jseaes.2011.09.014.

570

571

572

573

574

575

576

577

578

579

580

581

582

583

584

585

586

587

588

589

590

591

Hutchinson, D.K., Coxall, H.K., Lunt, D.J., Steinthorsdottir, M., De, A.M., Baatsen, M., Heydt, A. Von Der, Huber, M., Kennedy-Asser, A.T., Ladant, J.-B., Lear, C.H., Moraweck, K., Pearson, P.N., Pound, M.J., Salzmann, U., Scher, H.D., Sijp, W.P., Kasia, K.Ś., de Boer, A.M., Baatsen, M., von der Heydt, A., Huber, M., Kennedy-Asser, A.T., Kunzmann, L., Ladant, J.-B., Lear, C.H., Moraweck, K., Pearson, P.N., Piga, E., Pound, M.J., Salzmann, U., Scher, H.D., Sijp, W.P., nska, S., Wilson, P.A., Zhang, Z., 2021. The Eocene-Oligocene transition: a review of marine and terrestrial proxy data, models, and model-data comparisons 17, 269-315. https://doi.org/10.5194/cp-17269-2021.

Kohn, M.J., Strömberg, C.A.E., Madden, R.H., Dunn, R.E., Evans, S., Palacios, A., Carlini, A.A., 2015. Quasi-static Eocene-Oligocene climate in Patagonia promotes slow faunal evolution and mid-Cenozoic global cooling. Palaeogeography, Palaeoclimatology, Palaeoecology 435, 24-37. https://doi.org/10.1016/j.palaeo.2015.05.028.

Lauretano, V., Kennedy-Asser, A.T., Korasidis, V.A., Wallace, M.W., Valdes, P.J., Lunt, D.J., Pancost, R.D., Naafs, B.D.A., 2021. Eocene to Oligocene terrestrial Southern Hemisphere cooling caused by declining pCO2. Nat. Geosci. https://doi.org/10.1038/s41561-021-00788-z.

Li, S., Su, T., Spicer, R.A., Xu, C., Sherlock, S., Halton, A., Hoke, G., Tian, Y., Zhang, S., Zhou, Z., Deng, C., Zhu, R., 2020. Oligocene Deformation of the Chuandian Terrane in the SE Margin of the Tibetan Plateau Related to the Extrusion of Indochina. Tectonics 39, 1-17. https://doi.org/10.1029/2019TC005974. 
592

593

594

595

596

597

598

599

600

601

602

603

604

605

606

607

608

609

610

611

612

613

614

615

616

617

618

Li, S.F., Valdes, P.J., Farnsworth, A., Davies-Barnard, T., Su, T., Lunt, D.J., Spicer, R.A., Liu, J., Deng, W.Y.D., Huang, J., Tang, H., Ridgwell, A., Chen, L.L., Zhou, Z.K., 2021. Orographic evolution of northern Tibet shaped vegetation and plant diversity in eastern Asia. Science Advances 7, 7741-7768.

https://doi.org/10.1126/sciadv.abc7741.

Linnemann, U., Su, T., Kunzmann, L., Spicer, R.A., Ding, W.N., Spicer, T.E.V., Zieger, J., Hofmann, M., Moraweck, K., Gärtner, A., Gerdes, A., Marko, L., Zhang, S.T., Li, S.H., Tang, H., Huang, J., Mulch, A., Mosbrugger, V., Zhou, Z.K., 2018. New U-Pb dates show a Paleogene origin for the modern Asian biodiversity hot spots. Geology 46, 3-6. https://doi.org/10.1130/G39693.1.

Marzi, R., Torkelson, B.E., Olson, R.K., 1993. A revised carbon preference index, Org. Geochem.

Naafs, B.D.A., Gallego-Sala, A.V., Inglis, G.N., Pancost, R.D., 2017a. Refining the global branched glycerol dialkyl glycerol tetraether (brGDGT) soil temperature calibration. Organic Geochemistry 106, 48-56. https://doi.org/10.1016/J.ORGGEOCHEM.2017.01.009

Naafs, B.D.A., Inglis, G.N., Blewett, J., McClymont, E.L.L., Lauretano, V., Xie, S., Evershed, R.P.P., Pancost, R.D.R.D., 2019. The potential of biomarker proxies to trace climate, vegetation, and biogeochemical processes in peat: A review. Global and Planetary Change 179, 57-79. https://doi.org/10.1016/j.gloplacha.2019.05.006.

Naafs, B.D.A., Inglis, G.N., Zheng, Y., Amesbury, M.J., Biester, H., Bindler, R., Blewett, J., Burrows, M.A., del Castillo Torres, D., Chambers, F.M., Cohen, A.D., Evershed, R.P., Feakins, S.J., Gałka, M., Gallego-Sala, A., Gandois, L., Gray, D.M., Hatcher, P.G., Honorio Coronado, E.N., Hughes, P.D.M., Huguet, A., Könönen, M., LaggounDéfarge, F., Lähteenoja, O., Lamentowicz, M., Marchant, R., McClymont, E., Pontevedra-Pombal, X., Ponton, C., Pourmand, A., Rizzuti, A.M., Rochefort, L., Schellekens, J., De Vleeschouwer, F., Pancost, R.D., 2017b. Introducing global peat- 
619

620

621

622

623

624

625

626

627

628

629

630

631

632

633

634

635

636

637

638

639

640

641

642

643

644

645

specific temperature and $\mathrm{pH}$ calibrations based on brGDGT bacterial lipids.

Geochimica et Cosmochimica Acta 208, 285-301.

https://doi.org/10.1016/j.gca.2017.01.038.

Nott, C.J., Xie, S., Avsejs, L.A., Maddy, D., Chambers, F.M., Evershed, R.P., 2000. n-Alkane distributions in ombrotrophic mires as indicators of vegetation change related to climatic variation. Organic Geochemistry 31, 231-235. https://doi.org/10.1016/S01466380(99)00153-9.

Retallack, G.J., 2007. Cenozoic paleoclimate on land in North America. Journal of Geology 115, 271-294. https://doi.org/10.1086/512753.

Retallack, G.J., Orr, W.N., Prothero, D.R., Duncan, R.A., Kester, P.R., Ambers, C.P., 2004. Eocene-Oligocene extinction and paleoclimatic change near Eugene, Oregon. Bulletin of the Geological Society of America 116, 817-839. https://doi.org/10.1130/B25281.1.

Sheldon, N.D., Costa, E., Cabrera, L., Garcés, M., 2012. Continental Climatic and Weathering Response to the Eocene-Oligocene Transition. The Journal of Geology 120, 227-236. https://doi.org/10.1086/663984.

Sheldon, N.D., Grimes, S.T., Hooker, J.J., Collinson, M.E., Bugler, M.J., Hren, M.T., Price, G.D., Sutton, P.A., 2016. Coupling of marine and continental oxygen isotope records during the Eocene-Oligocene transition. Geological Society of America Bulletin 128, 502-510. https://doi.org/10.1130/B31315.1.

Sinninghe Damsté, J.S., Hopmans, E.C., Pancost, R.D., Schouten, S., Geenevasen, J.A.J., 2000. Newly discovered non-isoprenoid glycerol dialkyl glycerol tetraether lipids in sediments. Chemical Communications 1683-1684. https://doi.org/10.1039/b004517i

Spicer, R.A., Bera, Subir, De Bera, Sreelekha, Spicer, T.E.V., Srivastava, G., Mehrotra, R., Mehrotra, N., Yang, J., 2011. Why do foliar physiognomic climate estimates sometimes differ from those observed? Insights from taphonomic information loss and a CLAMP case study from the Ganges Delta. Palaeogeography, 
Palaeoclimatology, Palaeoecology 302, 381-395. https://doi.org/10.1016/j.palaeo.2011.01.024.

648 Spicer, R.A., Su, T., Valdes, P.J., Farnsworth, A., Wu, F.-X., Shi, G., Spicer, T.E.V., Zhou, 649 Z., 2020a. Why 'the uplift of the Tibetan Plateau' is a myth? National Science Review. https://doi.org/10.1093/nsr/nwaa091.

651

Spicer, R.A., Valdes, P., Hughes, A., Yang, J., Spicer, T., Herman, A., Farnsworth, A., 652 2020b. New insights into the thermal regime and hydrodynamics of the early Late Cretaceous Arctic. Geological Magazine 157, 1729-1746.

655 656 https://doi.org/10.1017/S0016756819000463.

Steinthorsdottir, M., Porter, A.S., Holohan, A., Kunzmann, L., Collinson, M., Mcelwain, J.C., 2016. Fossil plant stomata indicate decreasing atmospheric $\mathrm{CO}_{2}$ prior to the EoceneOligocene boundary. Clim. Past 12, 439-454. https://doi.org/10.5194/cp-12-4392016.

Su, T., Farnsworth, A., Spicer, R.A., Huang, J., Wu, F.-X., Liu, J., Li, S.-H., Xing, Y.-W., 660 Huang, Y.-J., Deng, W.-Y.-D., Tang, H., Xu, C.-L., Zhao, F., Srivastava, G., Valdes,

Su, T., Spicer, R.A., Li, S.F.S.H., Xu, H., Huang, J., Sherlock, S., Huang, Y.J., Li, S.F.S.H., 664 P.J., Deng, T., Zhou, Z.-K., 2019a. No high Tibetan Plateau until the Neogene. Science Advances 5, eaav2189. https://doi.org/10.1126/sciadv.aav2189. Wang, L., Jia, L.B., Deng, W.Y.D., Liu, J., Deng, C.L., Zhang, S.T., Valdes, P.J., Zhou, Z.K., 2019b. Uplift, climate and biotic changes at the Eocene-Oligocene transition in south-eastern Tibet. National Science Review 6, 495-504. Deng, W.-Y.-D., Huang, Y.-J., Hughes, A., Jia, L.-B., Jin, J.-H., Li, S.-F., Liang, S.-Q., Liu, J., Liu, X.-Y., Sherlock, S., Spicer, T., Srivastava, G., Tang, H., Valdes, P., Wang, T.-X., Widdowson, M., Wu, M.-X., Xing, Y.-W., Xu, C.-L., Yang, J., Zhang, C., Zhang, S.-T., Zhang, X.-W., Zhao, F., Zhou, Z.-K., 2020. A Middle Eocene lowland humid 
673

674

675

676

677

678

679

680

681

682

683

684

685

686

687

688

689

690

691

692

693

694

695

696

697

698

699

subtropical "Shangri-La" ecosystem in central Tibet. Proceedings of the National Academy of Sciences 202012647. https://doi.org/10.1073/pnas.2012647117.

Valdes, P.J., Armstrong, E., Badger, M.P.S., Bradshaw, C.D., Bragg, F., Crucifix, M., Davies-Barnard, T., Day, J.J., Farnsworth, A., Gordon, C., Hopcroft, P.O., KennedyAsser, A.T., Lord, N.S., Lunt, D.J., Marzocchi, A., Parry, L.M., Pope, V., Roberts, W.H.G., Stone, E.J., Tourte, G.J.L., Williams, J.H.T., 2017. The BRIDGE HadCM3 family of climate models: HadCM3@Bristol v1.0. Geosci. Model Dev 10, 3715-3743. https://doi.org/10.5194/gmd-10-3715-2017.

Weijers, J.W.H.H., Bernhardt, B., Peterse, F., Werne, J.P., Dungait, J.A.J., Schouten, S., Sinninghe Damsté, J.S., 2011. Absence of seasonal patterns in MBT-CBT indices in mid-latitude soils. Geochimica et Cosmochimica Acta 75, 3179-3190. https://doi.org/10.1016/j.gca.2011.03.015.

Weijers, J.W.H.H., Schouten, S., Sluijs, A., Brinkhuis, H., Sinninghe Damsté, J.S., 2007. Warm arctic continents during the Palaeocene-Eocene thermal maximum. Earth and Planetary Science Letters 261, 230-238. https://doi.org/10.1016/j.epsl.2007.06.033

Westerhold, T., Marwan, N., Drury, A.J., Liebrand, D., Agnini, C., Anagnostou, E., Barnet, J.S.K., Bohaty, S.M., De Vleeschouwer, D., Florindo, F., Frederichs, T., Hodell, D.A., Holbourn, A.E., Kroon, D., Lauretano, V., Littler, K., Lourens, L.J., Lyle, M., Pälike, H., Röhl, U., Tian, J., Wilkens, R.H., Wilson, P.A., Zachos, J.C., 2020. An astronomically dated record of Earth's climate and its predictability over the last 66 million years, Science. American Association for the Advancement of Science. https://doi.org/10.1126/science.aba6853.

Witkowski, C. R., Weijers, J. W. H., Blais, B., Schouten, S., Sinninghe Damsté, J. S.: Molecular fossils from phytoplankton reveal secular pCO2 trend over the Phanerozoic, Sci. Adv., 4, eaat4556, 2018.

Wolfe, J.A., 1993. A method of obtaining climatic parameters from leaf assemblages. US Geological Survey Bulletin 2040. 
Xu, J.-X., Ferguson, D.K., Li, C. Sen, Wang, Y.F., 2008. Late Miocene vegetation and climate of the Lühe region in Yunnan, southwestern China. Review of Palaeobotany and Palynology 148, 36-59. https://doi.org/10.1016/j.revpalbo.2007.08.004.

Yang, J., Spicer, R.A., Spicer, T.E.V., Li, C. Sen, 2011. "CLAMP Online”: A new web-based palaeoclimate tool and its application to the terrestrial Paleogene and Neogene of North America. Palaeobiodiversity and Palaeoenvironments 91, 163-183. https://doi.org/10.1007/s12549-011-0056-2.

Yi, T.M., Li, C. Sen, Xu, J.-X., 2003. Late Miocene woods of Taxodiaceae from Yunnan, China. Acta botanica Sinica 53, 1689-1699. https://doi.org/10.1017/CBO9781107415324.004.

Zanazzi, A., Kohn, M.J., Macfadden, B.J., Terry, D.O., 2007. Large temperature drop across the Eocene-Oligocene transition in central North America. Nature 445, 639-642. https://doi.org/10.1038/nature05551.

Zhang, Y., Ferguson, D.K., Ablaev, A.G., Wang, Y., Li, C., Xie, L., 2007. Equisetum cf. pratense (Equisetaceae) from the Miocene of Yunnan in Southwestern China and Its Paleoecological Implications. Internation Journal of Plant Science 168. 


\section{Tables}

717

718 Table 1. Asian regional impact: Climate model simulations (Sim.) with Eocene

719 (Priabonian) and Oligocene (Chattian) boundary conditions are used to test the response of

$720 \mathrm{pCO}_{2}$ and Tibetan topography configuration on temperature and precipitation. Green

721 indicates which parameters are included in the simulation. $p \mathrm{CO}_{2}$ is represented as either a

722 change from $4 x$ to $2 x$ pre-industrial $p \mathrm{CO}_{2}$ or no change in $p \mathrm{CO}_{2}$, and Tibetan topography

723 configuration is represented as only a valley, as only a plateau, or as a change from valley to

724 plateau (Val-to-Plat). The response is shown as change in mean annual temperature

$725\left(\triangle \mathrm{MAT},{ }^{\circ} \mathrm{C}\right)$ and change in mean annual precipitation ( $\left.\triangle \mathrm{MAP}, \mathrm{mm} / \mathrm{yr}\right)$.

\begin{tabular}{|c|c|c|c|c|c|c|}
\hline Sim. & $\boldsymbol{p C O}_{2}$ & Valley & Plateau & Val-to-Plat & $\boldsymbol{\Delta M A T}$ & $\boldsymbol{\Delta M A P}$ \\
\hline 1 & $4 \times$ to $2 \mathrm{x}$ & Yes & No & No & -6.0 & 150 \\
\hline 2 & Change & No & Yes & No & -6.0 & 198 \\
\hline 3 & Change & No & No & Yes & -6.2 & 182 \\
\hline 4 & No change & Yes & No & No & 1.4 & 167 \\
\hline 5 & No change & No & Yes & No & 1.7 & 173 \\
\hline 6 & No change & No & No & Yes & 1.2 & 199 \\
\hline
\end{tabular}


727 Table 2. Climate model simulations at different Tibetan topography (valley or plateau) for

728 Lühe Basin during the Chattian. Conditions: 2x pre-industrial $p \mathrm{CO}_{2}(560 \mathrm{ppm})$, latitude and

729 longitude $(21.1,101.2)$, rotated latitude and longitude $(29.9,96.9)$. Abbreviations: experiment

730 code (expt.), terrestrial lapse rate (Terr-Lapse), mean annual temperature (MAT, $\left.{ }^{\circ} \mathrm{C}\right)$, warm-

731 month mean temperature $\left(\mathrm{WMMT},{ }^{\circ} \mathrm{C}\right)$, cold-month mean temperature $\left(\mathrm{CMMT},{ }^{\circ} \mathrm{C}\right)$, and

732 mean annual precipitation (MAP, $\mathrm{mm} / \mathrm{yr}$ ).

\begin{tabular}{lcccccc}
\hline Tibetan topography & expt & Terr-Lapse & MAT & WMMT & CMMT & MAP \\
\hline $2.5 \mathrm{~km}$ valley & tfgkb & 3.67 & 19.0 & 24.8 & 12.12 & 2.63 \\
$4.5 \mathrm{~km}$ plateau & tfgkd & 4.83 & 18.9 & 24.5 & 12.15 & 2.73 \\
\hline
\end{tabular}


734 Table 3. CLAMP climate estimates based on the Lühe town section leaf flora and analysed

735 using the PhysgAsia2/Worldclim2 calibration. For more details on these metrics and how

736 they are obtained see (Spicer et al., 2020b). Row 1: Temperature-related parameters: mean

737 annual air temperature $\left(\mathrm{MAAT},{ }^{\circ} \mathrm{C}\right)$; warm month mean air temperature $\left(\mathrm{WMMAT},{ }^{\circ} \mathrm{C}\right)$; cold

738 month mean air temperature $\left(\mathrm{CMMAT}^{\circ}{ }^{\circ} \mathrm{C}\right)$; mean minimum temperature of the warmest

739 month (MinT.W, ${ }^{\circ} \mathrm{C}$ ); mean maximum temperature of the coldest month (MaxT.C, $\left.{ }^{\circ} \mathrm{C}\right)$. Row

740 2: Vapour pressure deficit parameters: mean annual vapour pressure deficit (VPD.ann,

$741 \mathrm{hPa}$ ); mean winter vapour pressure deficit (VPD.win, $\mathrm{hPa}$ ); mean spring vapour pressure

742 deficit (VPD.spr, hPa); summer vapour pressure deficit (VPD.sum, hPa); autumn vapour

743 pressure deficit (VPD.aut, hPa). Row 3: Precipitation and evapotranspiration-related

744 parameters: precipitation during the three consecutive wettest months (3-Wet, $\mathrm{cm})$;

745 precipitation during the three consecutive driest months (3-Dry, $\mathrm{cm})$; mean annual potential

746 evapotranspiration (PET.ann, mm); mean monthly potential evapotranspiration during the

747 warmest quarter (PET.wrm, mm); mean monthly potential evapotranspiration during the

748 coldest quarter (PET.cld, mm). Row 4: Humidity and enthalpy-related parameters: relative

749 humidity $(\mathrm{RH}, \%)$; specific humidity $(\mathrm{SH}, \mathrm{g} / \mathrm{kg})$; moist enthalpy (Enth, $\mathrm{kJ} / \mathrm{kg})$; thermicity i.e. a

750 measure of cumulative heat (Therm). Row 5: Growth-related parameters: length of the

751 growing season i.e. time when the mean temperature is $>10^{\circ} \mathrm{C}$ (LGS, months), growing

752 degree days $>0^{\circ} \mathrm{C}$ (GDD0); growing degree days $>5^{\circ} \mathrm{C}$ (GDD5); growing season

753 precipitation (GSP, cm); mean monthly growing season precipitation (MMGSP, cm). 


\begin{tabular}{|c|c|c|c|c|}
\hline \multicolumn{5}{|c|}{ Temperature-related parameters } \\
\hline MAAT $\left({ }^{\circ} \mathrm{C}\right)$ & WMMAT $\left({ }^{\circ} \mathrm{C}\right)$ & CMMAT $\left({ }^{\circ} \mathrm{C}\right)$ & MinT.W $\left({ }^{\circ} \mathbf{C}\right)$ & $\operatorname{MaxT} . C\left({ }^{\circ} \mathrm{C}\right)$ \\
\hline $15.9 \pm 2.4$ & $26.8 \pm 2.9$ & $4.6 \pm 3.5$ & $23 \pm 2.9$ & $10.4 \pm 3.5$ \\
\hline \multicolumn{5}{|c|}{ Vapour pressure deficit parameters } \\
\hline VPD.ann (hPa) & VPD.win (hPa) & VPD.spr (hPa) & VPD.sum (hPa) & VPD.aut (hPa) \\
\hline $6 \pm 2.4$ & $3.2 \pm 1.5$ & $4.7 \pm 4$ & $8.7 \pm 3.5$ & $7.4 \pm 2$ \\
\hline \multicolumn{5}{|c|}{ Precipitation and evapotranspiration-related parameters } \\
\hline 3-Wet (cm) & 3-Dry (cm) & PET.ann (mm) & PET.cld (mm) & PET.wrm (mm) \\
\hline $111 \pm 40$ & $35 \pm 10$ & $1002 \pm 166$ & $27.5 \pm 14$ & $125 \pm 24.5$ \\
\hline \multicolumn{5}{|c|}{ Humidity and enthalpy-related parameters } \\
\hline $\mathbf{R H}(\%)$ & $\mathrm{SH}(\mathrm{g} / \mathrm{kg})$ & Enth (kJ/kg) & & Therm $\left({ }^{\circ} \mathbf{C}\right)$ \\
\hline $65 \pm 10$ & $8.3 \pm 1.8$ & $321 \pm 0.8$ & & $295 \pm 75$ \\
\hline \multicolumn{5}{|c|}{ Growth-related parameters } \\
\hline LGS (month) & GSP (cm) & MMGSP (cm) & GDD0 & GDD5 \\
\hline $9.8 \pm 1.1$ & $225 \pm 64$ & $24 \pm 7$ & $677 \pm 118$ & $735 \pm 106$ \\
\hline
\end{tabular}



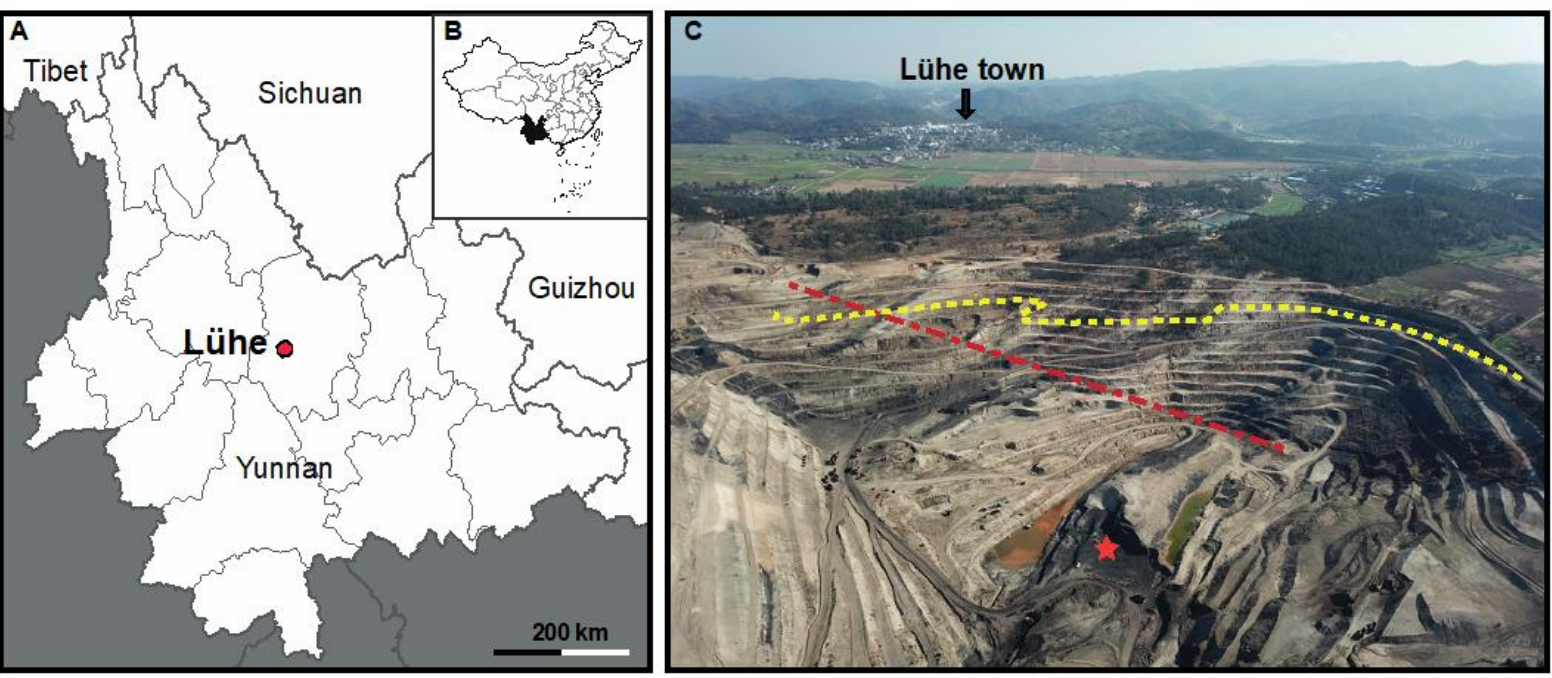

755

Fig. 1. Location and overview of the Lühe coal mine section. A-B: Location map

$757\left(25^{\circ} 10^{\prime} \mathrm{N}, 101^{\circ} 22^{\prime} \mathrm{E}\right)$. C. Photograph of Lühe coalmine (yellow line indicated the sampling log

758 of this study, red indicates the section logged by Li et al., 2020). 


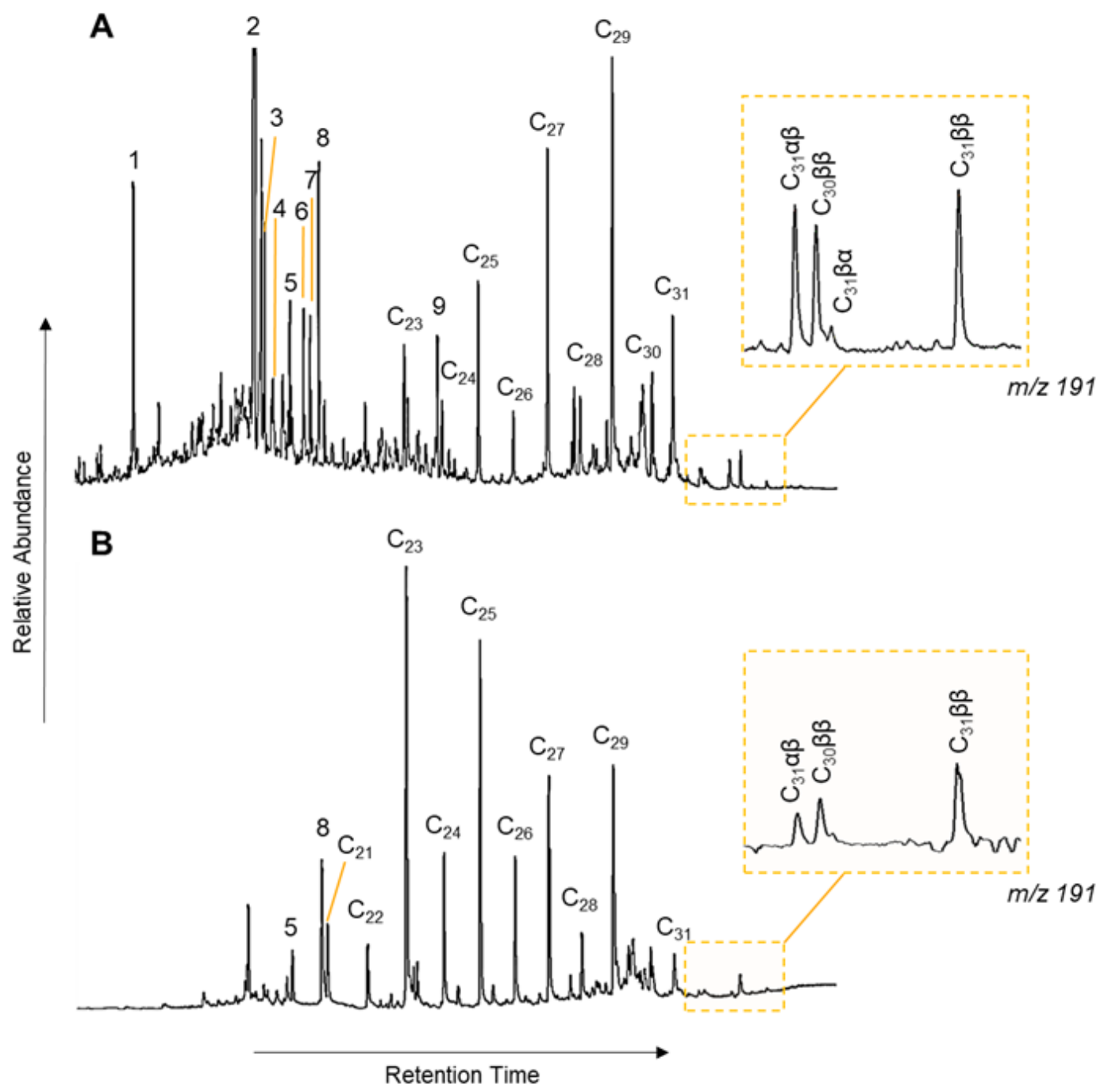

Fig. 2: Total ion chromatograms of the apolar fraction. A) Depth from base $268.0 \mathrm{~m}$ with

761 high content of terpenoids and $n$-alkanes exemplary of the section, especially the $\mathrm{C}_{29} n$ -

762 alkane dominance. B) Depth from base $58.5 \mathrm{~m}$ exemplary of the two outliers with $\mathrm{C}_{23}$ and

$763 \quad \mathrm{C}_{25} n$-alkane dominance. Numbers represent: 1. Cadalene, 2. Norpimerane, 3. 18-

764 norbietane, 4. 18-norabieta-8,11,13-triene, 5. Dehydroabietane, 6. 10,18-Bisnorabieta-

765 5,7,9(10),11,13-pentaene, 7. Naphtalene, 8. Simonellite, 9. Tetramethyl-octahydrochrysene.

766 Gold boxes zoom in on m/z 191 i.e., hopanes used for the thermal maturity index. 
A

$C_{31} \beta \beta /(\beta \beta+\alpha \beta+\beta \alpha)$

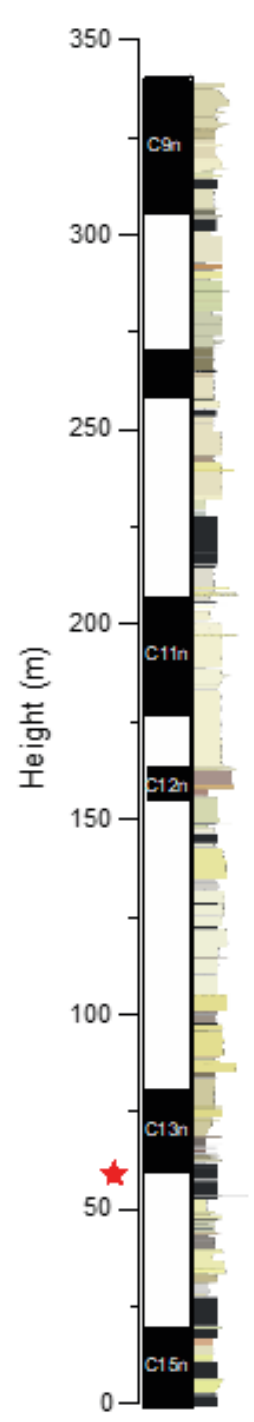

B

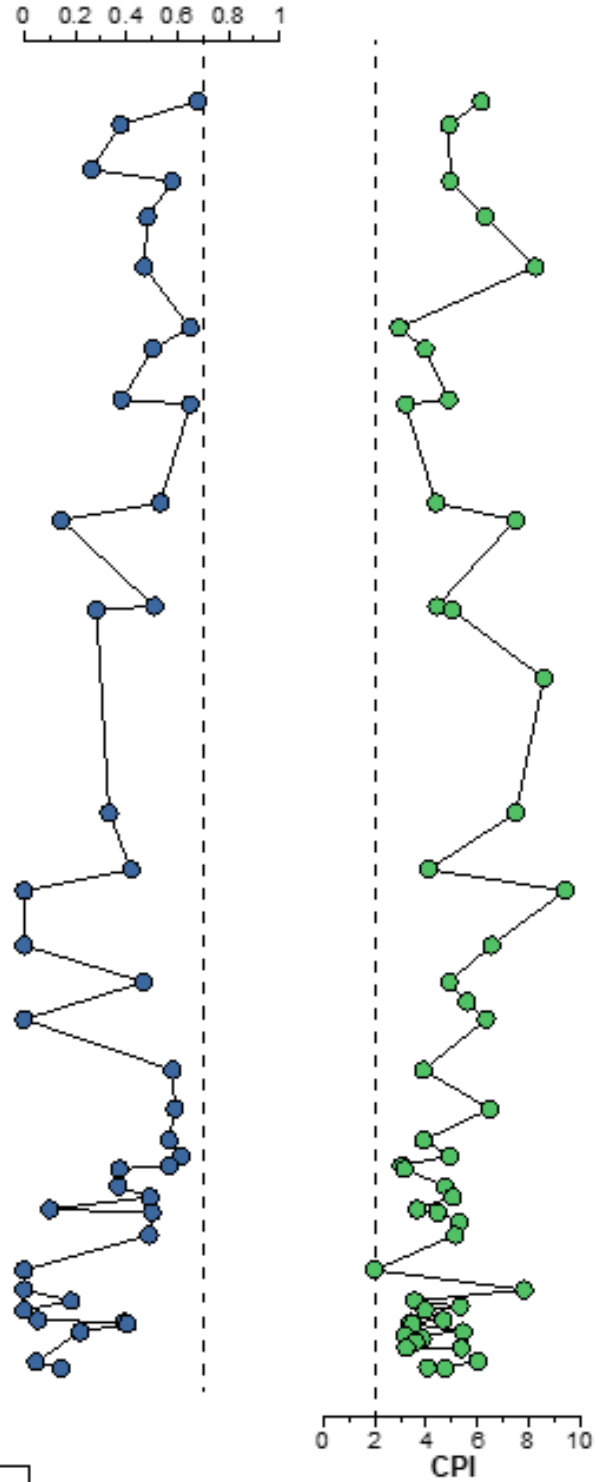

C

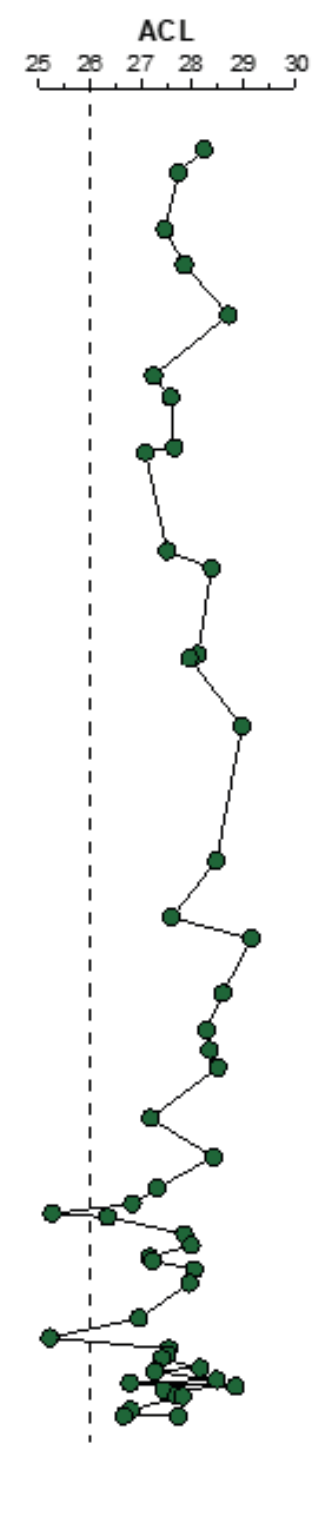

D

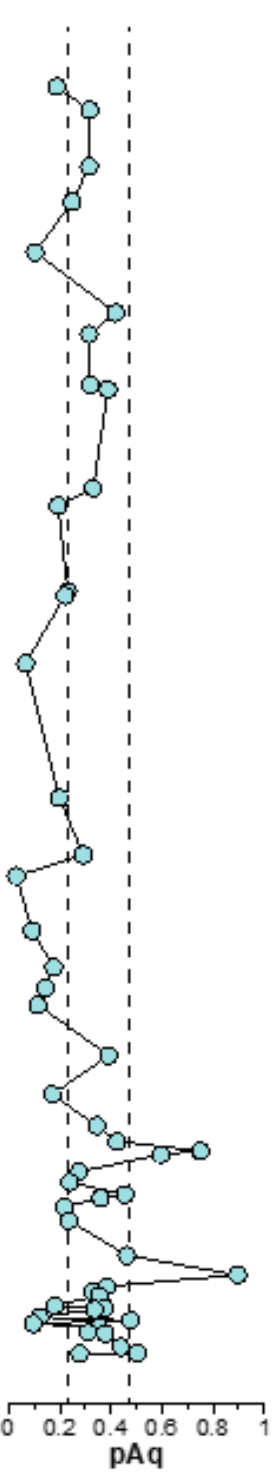

768 Fig. 3. Apolar biomarker indices for thermal maturity, vegetation, and environmental

769 reconstructions. A) $\mathrm{C}_{31}$ hopane configuration ratio, B) Carbon preference index (CPI), C)

770 Average chain length $(\mathrm{ACL})$, and $\mathrm{D}) P$-aqueous ratio $\left(P_{\text {aq }}\right)$ which shows terrestrial versus

771 aquatic input. Dotted lines: $A)$ and $B)$ limits for thermal maturity $\left(C_{31}\right.$ hopane ratio $>0.6$, $C P I$ $772<2.0), C)$ terrestrial higher plants $(A C L>26)$, and $D)$ terrestrial plant waxes $(\mathrm{aq}<0.23)$ and 773 submerged and floating macrophytes $\left(P_{\mathrm{aq}}>0.48\right)$ (see text). 


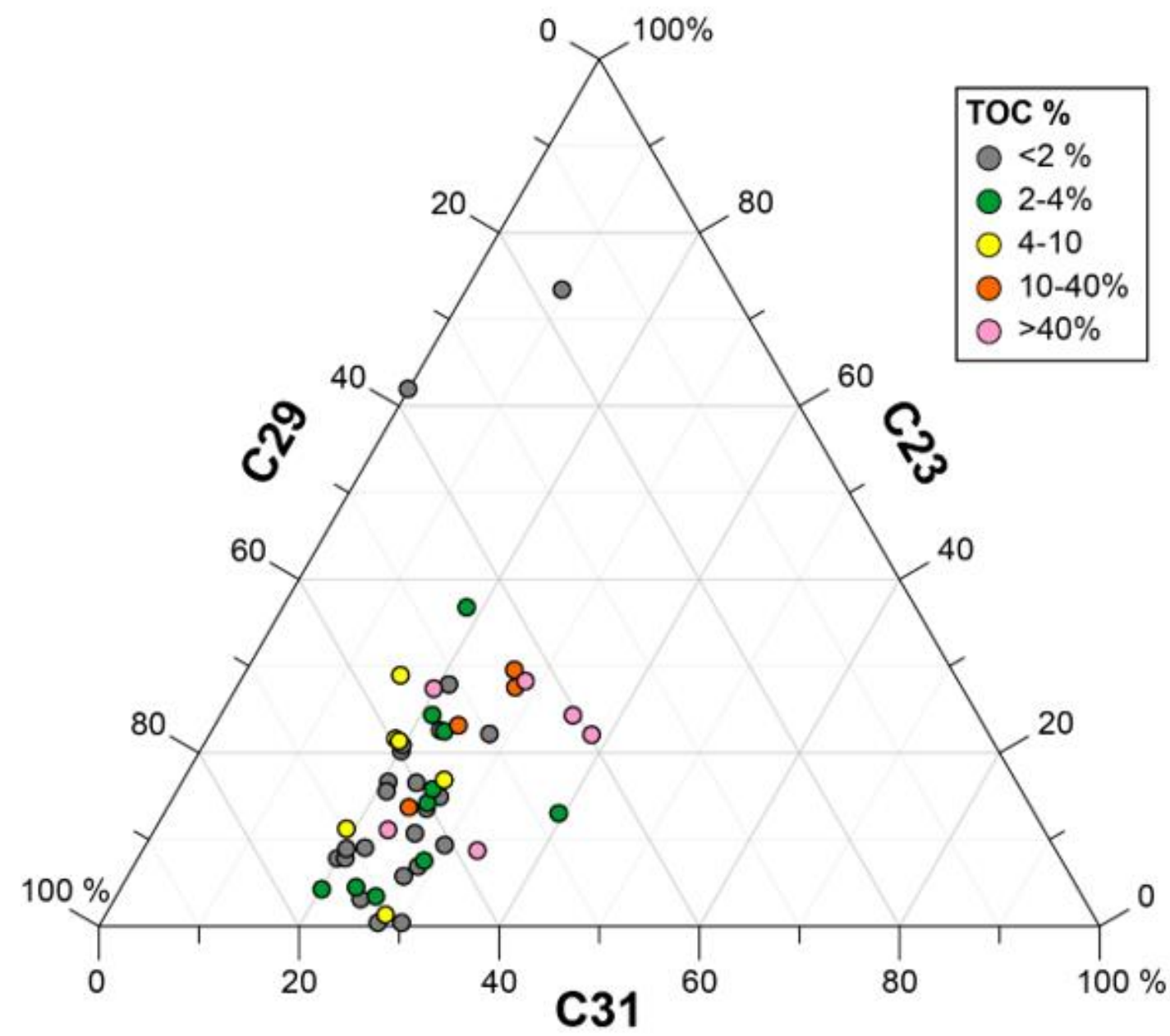

774

Fig. 4: Ternary plots of diagnostic $n$-alkanes. The relative percentage of $C_{23}, C_{29}$, and $C_{31}$

$776 n$-alkanes in samples, differentiated based on their total organic content (TOC, \%). 

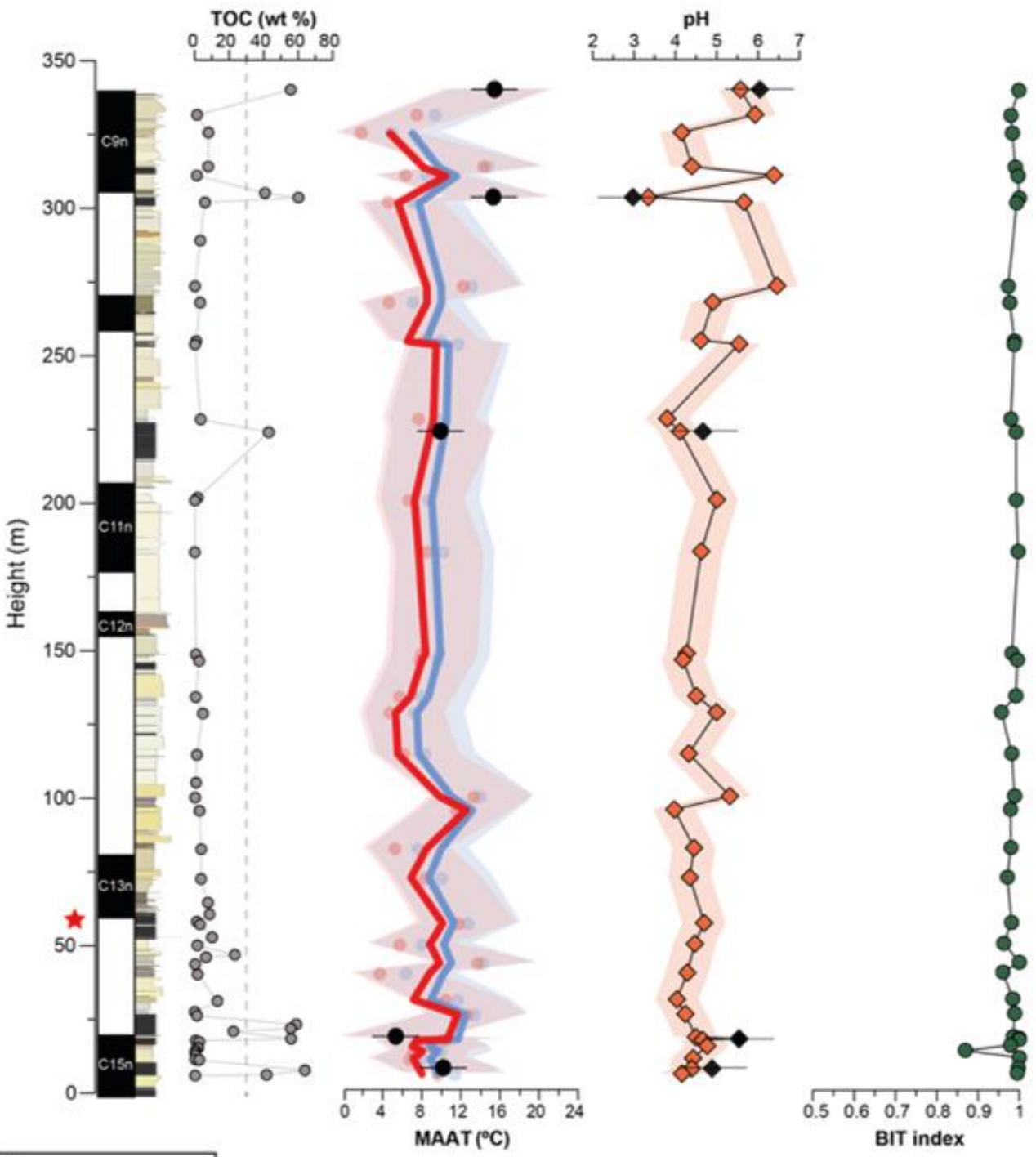

778 Fig. 5. TOC\% and GDGT-derived proxies at Lühe coalmine: Total organic content (TOC

$779 \%)$ for each analysed sample was used to constraint organic content and differentiate lignite 780 samples $(\mathrm{TOC}>30 \%)$. $\mathrm{MAAT}_{\text {soil }}$ (mean annual air temperatures) and $\mathrm{pH}$ following: two soil 781 calibrations in purple (De Jonge et al., 2014; Naafs et al., 2017a) and the peat-specific 782 calibration in black (Naafs et al., 2017b) and Branched and Isoprenoid Tetraether (BIT) index (Hopmans et al., 2004). 


\section{Methods}

\section{TOC (wt \%) analyses}

Total Organic Carbon (TOC) was determined on 56 samples using an Elementar vario PYRO cube at the University of Bristol, analysing C/N/S via catalytic combustion/reduction $\left(1150^{\circ} \mathrm{C}\right)$, optimised for coupling with an Isoprime IRMS for simultaneous determination of stable isotope ratios of $\mathrm{C}$ and $\mathrm{N}$. Detection limits are at $0.001 \%$ or $10 \mathrm{ppm}$ for $\mathrm{C} / \mathrm{N} / \mathrm{S}$. An NC Soil reference standard was used to determine analytical precision. Prior to the analyses, all samples were prepared through an acid pre-treatment for carbonate removal, following the method by Hedges and Stern (1984).

\section{Lipid extraction}

796

For 56 samples from the Lühe coalmine section, $5 \mathrm{~g}$ of freeze-dried homogenised sediment were extracted using an Ethos Ex microwave extraction system with $20 \mathrm{ml}$ of dichloromethane $(\mathrm{DCM})$ and methanol $(\mathrm{MeOH})(9: 1 \mathrm{v} / \mathrm{v})$. Microwave extractions were set using a 10 -minute ramp to $70^{\circ} \mathrm{C}(1000 \mathrm{~W})$, a 10 -minute hold at $70^{\circ} \mathrm{C}(1000 \mathrm{~W})$, and 20 -minute cooling. Samples were then centrifuged at 1700 revolutions per minute (rpm) for 5 min to promote extract and sediment separation. Supernatants were removed and collected, and about $10 \mathrm{~mL}$ of $\mathrm{DCM}: \mathrm{MeOH}(9: 1 \mathrm{v} / \mathrm{v})$ was added to the remaining sample and centrifuged again, before combining the available supernatants. This procedure was repeated up to five

804 times to maximise lipid extraction. Elemental sulphur was removed by the addition of

805 activated copper to the total lipid extract (TLE), left overnight. The TLE was concentrated by rota-evaporation and washed through a 4-cm sodium sulphate column using DCM:MeOH

$807(9: 1, v / v)$ to remove sediment particles. Subsequently, the TLE was split in two aliquots, and one of these was separated over a 4-cm alumina column by elution in an apolar fraction using hexane:DCM (9:1 v/v, $5 \mathrm{ml})$, and a polar fraction using DCM:MeOH (1:2 v/v, $4 \mathrm{ml})$. The apolar fraction was re-dissolved in hexane and analysed by GC-MS. The polar fraction was 
811 re-dissolved in hexane:isopropanol $(99: 1, \mathrm{v} / \mathrm{v})$ and passed through a $0.45 \mu \mathrm{m}$

812 polytetrafluoroethylene filter before analyses by HPLC-MS.

\section{GC-MS}

814 Apolar fractions were analysed at the University of Bristol using a Thermo Scientific ISQ

815 Single Quadruple gas chromatography mass spectrometry (GC-MS) system, fitted with a

816 fused HP-1 silica capillary column (50 m x $0.32 \mathrm{~mm}$ i.d., $0.17 \mu \mathrm{m}$ film diameter). Using helium

817 as the carrier gas, $1 \mu \mathrm{L}$ of sample dissolved in hexane was injected at $70{ }^{\circ} \mathrm{C}$ using an on-

818 column PTV injector in splitless mode. The temperature program was set to four stages:

$81970^{\circ} \mathrm{C}$ hold for $1 \mathrm{~min}$, ramping to $130^{\circ} \mathrm{C}$ at $20^{\circ} \mathrm{C} / \mathrm{min}$, then ramping to $300^{\circ} \mathrm{C}$ at $4{ }^{\circ} \mathrm{C} / \mathrm{min}$, and

820 finally holding $300{ }^{\circ} \mathrm{C}$ for $20 \mathrm{~min}$. The electron ionisation (El) source was set at $70 \mathrm{eV}$. The

821 emission current was set to $150 \mu \mathrm{A}$ and scanning occurred between $\mathrm{m} / \mathrm{z}$ ranges of $50-650$

822 Daltons in full scan mode. The instrument accuracy was determined using an external fatty

823 acid methyl ester (FAME) standard. Compound identification was carried out based on

824 published spectra, characteristic mass fragments, and retention times.

\section{HPLC-MS}

826 Filtered polar fractions were analysed by high performance liquid

827 chromatography/atmospheric pressure chemical ionisation - mass spectrometry

828 (HPLC/APCI-MS), using a ThermoFisher Scientific Accela Quantum Access Triple

829 quadrupole MS at the University of Bristol. Normal phase separation was achieved using two

830 Waters Acquity UPLC BEH Hilic columns $(2.1 \times 150 \mathrm{~mm} ; 1.7 \mu \mathrm{m}$ i.d.) with a flow rate of 0.2

$831 \mathrm{ml} \mathrm{min}{ }^{-1}$, following the method by Hopmans et al. (2016). Samples were eluted using a

832 linear gradient of hexane hexane:IPA (9:1, v/v) (Hopmans et al., 2016), from an injection

833 volume of $15 \mu \mathrm{L}$, out of $100 \mu \mathrm{L}$. Analyses were performed using selective ion monitoring

834 mode (SIM) to increase sensitivity and reproducibility $(m / z 1302,1300,1298,1296,1294$,

$8351292,1050,1048,1046,1036,1034,1032,1022,1020,1018,744$, and 653$)$, and $\mathrm{M}+\mathrm{H}+$

836 (protonated molecular ion) GDGT peaks were manually integrated. 


\section{Supplement references}

839 Hopmans, E.C., Schouten, S., Sinninghe Damsté, J.S., 2016. The effect of improved

840 chromatography on GDGT-based palaeoproxies. Organic Geochemistry 93, 1-6.

841 https://doi.org/10.1016/j.orggeochem.2015.12.006. 
la

Ib ${ }^{10}$

Ic ${ }^{H 1}$

Ila

lla"

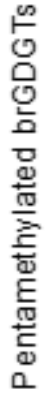

IIb

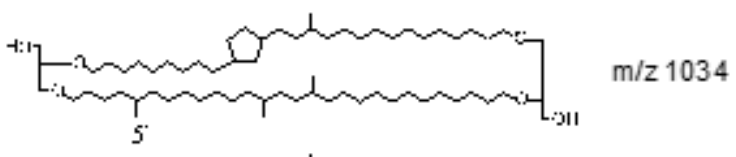

IIb'

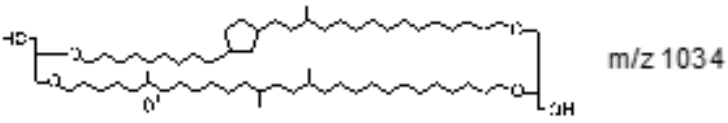

IIc

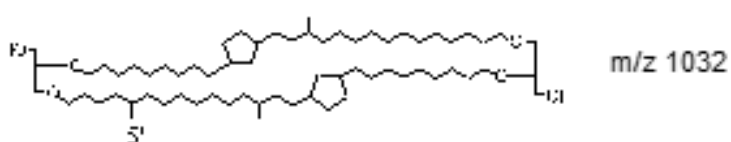

IIc'
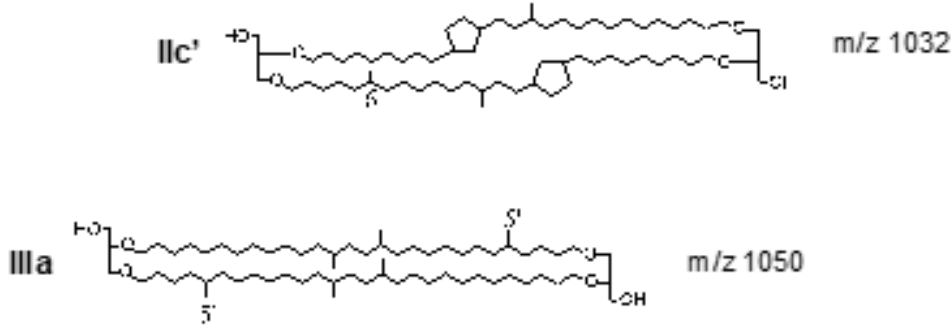

IIIa'

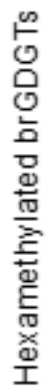
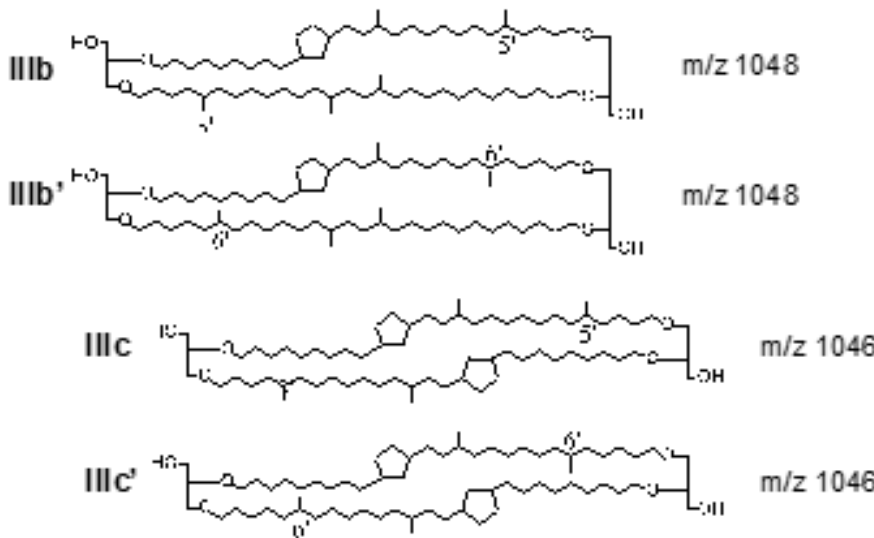

843 Fig. S1. Structures of brGDGTs, as discussed in the text. 